\title{
Comparative Examination of the Primary School Science Curricula in Turkey (Curricula of 1992, 2001, 2005, 2013 and 2017)
}

\author{
Hülya Hamurcu ${ }^{1}$ \\ ${ }^{1}$ Elementary Education Department, Buca Faculty of Education, Dokuz Eylül University, İzmir, Turkey \\ Correspondence: Hülya Hamurcu, Elementary Education Department, Buca Faculty of Education, Dokuz Eylül \\ University, İzmir, Turkey. E-mail:hulya.hamurcu@deu.edu.tr
}

Received: October 31, 2017

Accepted: January 11, 2018 Online Published: February 5, 2018

doi:10.5539/jel.v7n2p261

URL: http://doi.org/10.5539/jel.v7n2p261

\begin{abstract}
In the present study, the science course curricula of 1992, 2001, 2005, 2013 and 2017 taught at the primary school level in Turkey have been examined comparatively in terms of four main elements (Target, Content, Educational Status, and Measurement and Evaluation). The reason for investigating the science curriculum at five key years was to identify and examine main changes in the system. To this end, the main elements of the curricula were presented in a table. The similarities and differences between the curricula in question were determined and interpreted as a result of the evaluations. The study was carried out using the document review technique, among qualitative research methods. The science curricula published by the Ministry of National Education were analysed in the study. The curricula of the afore-mentioned years were first analysed separately in the process, and then the results were re-investigated by being gathered together. Therefore, it was attempted to ensure the consistency of the data. The results achieved show that the curricula cannot be realized as expected due to certain problems encountered in the process of implementation despite overall positive developments (the fact that teachers are not informed sufficiently, infrastructure problems, crowded classes, the lack of technological equipment, etc.)
\end{abstract}

Keywords: primary school, primary school science course curricula, main elements of the curriculum, learning theories

\section{Introduction}

When the phased classification of programs is examined, the terms Education program, Curriculum and Syllabus are generally confused. While an Education program is shortly defined as "a set-up of learning experiences" (Varış, 1994), a Curriculum is the planned preparation of what is meant to be learned by students (knowledge, skills, attitudes, gains, etc.) in the form of lesson clusters in line with the aims of the education program. The syllabus incorporates the aim, content, teaching and learning processes and evaluation features of a subject. In educational processes, the term "course curriculum" is generally used together, and it is assumed that it incorporates all these activities of that subject. The term curriculum will be used in the present study, by sticking to the term that is also used by the MNE (Ministry of National Education/MEB). According to Taba (1962), there are 4 main elements that a curriculum must have. These are as follows: 1) Aim and specific objectives, 2) Content, 3) Teaching and learning process, and 4) Evaluation (quoted by Saylan, 1995, pp. 36-37). Countries change and renew their education programs and curricula from time to time according to the requirements of the time. In Turkey, either the education programs of an educational level are fully renewed, or the curricula of specific subjects are revised. The curricula of the Science course at the primary school level, which is the subject of this study, were renewed on different dates throughout the years, and researchers conducted different studies on these changes (Hamurcu, 1998; Çepni, Küçük, \& Ayvacı, 2003; Ünal, Çoştu, \& Karataş, 2004; Bahar, 2006; Buluş Kırıkkaya \& Tanrıverdi, 2006; Bağcı Kılıç, Haymana, \& Bozyılmaz, 2008; Eş \& Sarıkaya, 2010; Dindar \& Taneri; 2011). Furthermore, similar studies were carried out in terms of different variables on the process of implementation of science curricula. Among these studies, it is observed that the studies on the process of implementation and content of the new Science and technology curriculum that was started to be implemented in 2004 are especially high in number (Bümen, 2005; Akpınar, Günay, \& Hamurcu, 2005; Akamca Özyılmaz, Hamurcu, \& Günay, 2006; Akamca Özy1lmaz, Hamurcu, \& Günay, 2008; Gömleksiz \& Bulut, 2007; Yangın \& Dindar, 2007; Tekbıyık \& Akdeniz, 2008; Buluş Kırıkkaya, 2009; Tüysüz \& Aydın, 2009; Aktaş \& Hamurcu, 
2010; Güçlü, Kartal, \& Mete, 2010; Aktaş \& Unayağyol, 2010; Hamurcu \& Günay, 2011). It is also observed that new studies have been carried out on the curricula in recent years (Karatay, Timur, \& Timur, 2013; Toraman \& Alc1, 2013; Özdemir \& Arık, 2017).

This study examines the Science curricula implemented in 1992, 2001, 2005, 2013 and 2017, in terms of the main elements of the curriculum. The aim of carrying out the research starting from the 1992 curriculum is to evaluate the main changes in the system, teaching approaches, practices, etc. As of 2001, the main learning approach on which the curriculum is based has been regulated based on Cognitive learning theories. In the recent period (2013), primary education has been regulated as 4 years of primary school and 4 years of secondary school in line with the change made in the education system (the $4+4+4$ model). With this change, the 5 th grades that were previously taught by primary school teachers have been included in the scope of secondary school. Furthermore, it was planned to teach the subject named Science in this new system 3 hours a week in the 3rd and 4th grades. Therefore, the term primary school used in the title of the study was used to cover the change that occurred in the Science course curricula taught by primary school teachers in the system from past to present. The 1992 Science 4th and 5th grade, 2001 Science 4th and 5th grade, 2005 Science and technology 4th and 5th grade, 2013 Science 3rd and 4th grade Curricula, and the recently published 2017 Science 3rd and 4th grade curricula will be addressed and examined in the present study in terms of 1) Aim and gains, 2) Content, 3) Teaching and learning process (educational status) and 4) Evaluation dimensions.

\section{Method}

The study was conducted using the Document review technique among the Qualitative research methods. Curricula, etc. can be used as a source of data in this method (Yıldırım \& Şimşek, 2000, pp. 140-141). The Science curricula published by the MNE (MEB) were analysed in the study. The curricula of the afore-mentioned years were first analysed by the researcher, and then re-investigated by another expert. Therefore, it was attempted to ensure the consistency of the data. The help of an academician, expert in the field of Education Programs and Teaching, was sought for deciding on the content of which program element the sub-dimensions belong to in the process of analysis. The analysis results are presented below in tables of the four main elements of the curriculum.

\section{Findings and Interpretation}

The differences of the main elements of the curriculum with the analysis of the qualitative data of the study are presented in the tables. Furthermore, there is interpretation of the data under each table.

\subsection{Aim and Gains (targets) Element of the Curriculum}

Features such as the knowledge, skills, attitudes, behaviours, etc. that are desired to be introduced to the student by a curriculum make up the first element of the curriculum. While each curriculum covers the aims of a subject at the beginning, these are followed by the specific targets or gains at varying numbers for each unit/subject in line with the learning approach on which the curriculum is based. The following Table 1 includes information on this distinction. 
Table 1. Differences in relation to the aim and gains (targets) element of the science curricula

\begin{tabular}{|c|c|c|c|c|c|}
\hline $\begin{array}{l}\text { NAME } \\
\text { OF THE } \\
\text { LESSON } \\
\text { Curriculum } \\
\text { Features } \\
\end{array}$ & $\begin{array}{l}\text { SCIENCE } \\
1992\end{array}$ & $\begin{array}{l}\text { SCIENCE } \\
2001\end{array}$ & $\begin{array}{l}\text { SCIENCE and } \\
\text { TECHNOLOGY } \\
2005\end{array}$ & $\begin{array}{l}\text { SCIENCE } \\
2013\end{array}$ & $\begin{array}{l}\text { SCIENCE } \\
2017\end{array}$ \\
\hline 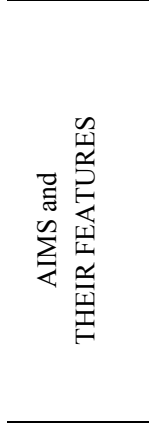 & $\begin{array}{l}\text { There are } 22 \text { general } \\
\text { aims. While the first } \\
14 \text { of them have } \\
\text { expressions that are } \\
\text { close to the general } \\
\text { aims, the subsequent } \\
\text { ones (between 15-22) } \\
\text { aim to introduce the } \\
\text { targets of the subject } \\
\text { area more (1992, p. } \\
81) \text {. }\end{array}$ & $\begin{array}{l}\text { There are } 10 \\
\text { general aims. } \\
\text { The aims } \\
\text { consist of } \\
\text { general } \\
\text { expressions. } \\
\text { (2000, p. 1013) }\end{array}$ & $\begin{array}{l}\text { There are } 11 \text { general } \\
\text { aims. } \\
\text { The aims consist of } \\
\text { general expressions } \\
\text { (2008, p. 1028). }\end{array}$ & $\begin{array}{l}\text { There are } 12 \text { general } \\
\text { aims in the curriculum. } \\
\text { The aims consist of } \\
\text { general expressions } \\
(2013, \text { p. II) }\end{array}$ & $\begin{array}{l}\text { There are } 10 \\
\text { general aims in } \\
\text { the curriculum. } \\
\text { The aims } \\
\text { consist of } \\
\text { general } \\
\text { expressions. } \\
(2017, \text { p. 5) }\end{array}$ \\
\hline 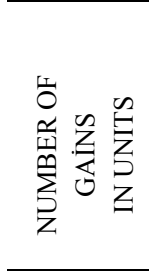 & $\begin{array}{l}\text { Each unit covers the } \\
\text { Aims and Behaviours. } \\
\text { The number of aims } \\
\text { varies by units, and a } \\
\text { varying number of } \\
\text { behaviours is shown } \\
\text { under each aim. }\end{array}$ & $\begin{array}{l}\text { The numbers of } \\
\text { specific aims } \\
\text { and gains in the } \\
\text { curriculum vary } \\
\text { by units. }\end{array}$ & $\begin{array}{l}\text { There is no specific } \\
\text { aim in the units. } \\
\text { The number of gains } \\
\text { varies by units }\end{array}$ & $\begin{array}{l}\text { There is no specific aim } \\
\text { in the units. } \\
\text { The number of gains } \\
\text { varies by units. }\end{array}$ & $\begin{array}{l}\text { There is no } \\
\text { specific aim in } \\
\text { the units. } \\
\text { The number of } \\
\text { gains varies by } \\
\text { units. }\end{array}$ \\
\hline 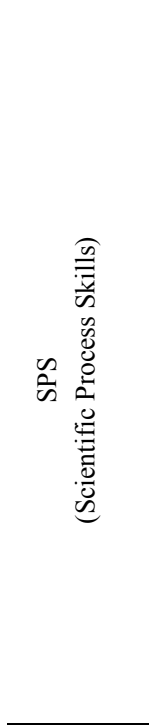 & $\begin{array}{l}\text { Despite not being fully } \\
\text { expressed as SPS in } \\
\text { the general aims, it } \\
\text { was mentioned as } \\
\text { content (in aim 4-5-6). } \\
\text { Furthermore, the } \\
\text { building of the same } \\
\text { content and } \\
\text { problem-solving skill } \\
\text { was mentioned in the } \\
\text { Introduction part } \\
\text { (1992, pp. 8-9). }\end{array}$ & $\begin{array}{l}\text { SPS were } \\
\text { mentioned in } \\
\text { the general } \\
\text { aims. The } \\
\text { observation, } \\
\text { research and } \\
\text { experiment } \\
\text { making skills } \\
\text { were especially } \\
\text { emphasised } \\
\text { (2000, p. 1013). }\end{array}$ & $\begin{array}{l}\text { SPS were included as } \\
\text { the 4th dimension } \\
\text { among } 7 \text { dimensions } \\
\text { for science and } \\
\text { technology literacy } \\
\text { specified in the vision } \\
\text { of the science and } \\
\text { technology course. } \\
\text { SPS were mentioned } \\
\text { in the 8th item of the } \\
\text { Aims of the } \\
\text { Curriculum of the } \\
\text { Science and } \\
\text { Technology Course } \\
\text { Furthermore, SPS are } \\
\text { included under a } \\
\text { separate title in the } \\
\text { curriculum (2008, pp. } \\
\text { 1113-1114). }\end{array}$ & $\begin{array}{l}\text { SPS were explicitly } \\
\text { referred to in the general } \\
\text { aims (Aim } 2 \text { and } 6 ; \\
2013 \text {, p. II). }\end{array}$ & $\begin{array}{l}\text { SPS were } \\
\text { referred to in } \\
\text { the general aims } \\
\text { (Aims 2, } 4 \text { and } \\
9 ; 2017, \text { p. 5). }\end{array}$ \\
\hline$\frac{Z}{0}$ & 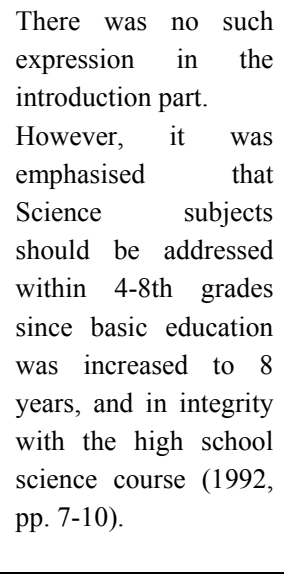 & $\begin{array}{l}\text { The } \\
\text { introduction } \\
\text { part of the } \\
\text { curriculum } \\
\text { includes the } \\
\text { general } \\
\text { definitions in } \\
\text { relation to } \\
\text { vision, and what } \\
\text { the vision of the } \\
\text { curriculum was } \\
\text { mentioned as a } \\
\text { section of } 7 \\
\text { items (2000, p. } \\
1005) \text {. }\end{array}$ & $\begin{array}{l}\text { The vision of the } \\
\text { Science and } \\
\text { Technology Course } \\
\text { Curriculum is said to } \\
\text { be "Raising all } \\
\text { students as science } \\
\text { and technology } \\
\text { literate regardless of } \\
\text { their individual } \\
\text { differences" } \\
\text { (2008, p. 1111). }\end{array}$ & $\begin{array}{l}\text { The vision of the Science } \\
\text { Course Curriculum was } \\
\text { defined as "Raising all } \\
\text { students as science } \\
\text { literate individuals" } \\
(2013, \text { p. I). }\end{array}$ & $\begin{array}{l}\text { Such an } \\
\text { expression was } \\
\text { not included in } \\
\text { the introduction. } \\
\text { However, it was } \\
\text { specified that } \\
\text { this curriculum } \\
\text { aims to "Raise } \\
\text { all individuals } \\
\text { as science } \\
\text { literate" right } \\
\text { before the } \\
\text { general aims } \\
(2017, \text { p. 5). }\end{array}$ \\
\hline
\end{tabular}




\begin{tabular}{|c|c|c|c|c|c|}
\hline 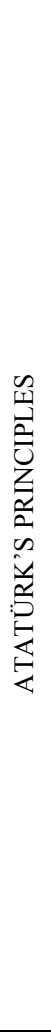 & $\begin{array}{l}\text { There is no association } \\
\text { with Atatürk's } \\
\text { Principles and } \\
\text { Reforms in the } \\
\text { Curriculum. }\end{array}$ & $\begin{array}{l}\text { The "Subjects } \\
\text { Related to } \\
\text { Atatürkism" in } \\
\text { the curriculum } \\
\text { were fully } \\
\text { addressed in the } \\
\text { units of the 4th } \\
\text { and 5th grades. }\end{array}$ & $\begin{array}{l}\text { There no } \\
\text { association with } \\
\text { Atatürk's Principles } \\
\text { and Reforms in the } \\
\text { introduction part of } \\
\text { the curriculum. } \\
\text { However, it includes } \\
\text { tables on the subjects } \\
\text { related to Atatürkism } \\
\text { that match the gains of } \\
\text { the 4th and 5th-grade } \\
\text { science and } \\
\text { technology course } \\
\text { curriculum par } \\
\text { (2008, } \\
\text { 1076-1110). }\end{array}$ & $\begin{array}{l}\text { There is no association } \\
\text { with Atatürk's Principles } \\
\text { and Reforms in the } \\
\text { curriculum. }\end{array}$ & $\begin{array}{l}\text { There is no } \\
\text { association with } \\
\text { Atatürk's } \\
\text { Principles and } \\
\text { Reforms in the } \\
\text { curriculum. } \\
\text { The curriculum } \\
\text { mentions } \\
\text { Atatürk's name } \\
\text { only under the } \\
\text { title of Science } \\
\text { and engineering } \\
\text { practices, and it } \\
\text { was said that } \\
\text { "The } \\
\text { importance } \\
\text { attributed by } \\
\text { Atatürk to } \\
\text { science and } \\
\text { technology is } \\
\text { emphasised in } \\
\text { the units of } \\
\text { science and } \\
\text { engineering } \\
\text { practices at all } \\
\text { grade levels" } \\
\text { (2017, p. 11). }\end{array}$ \\
\hline
\end{tabular}

When the table is examined, it is observed that while the number of the general aims in the Science curriculum was first 22 in 1992, it was similar in other years $(10,11,12$ and 10). The change in the content of the aims can also be observed clearly. While the 1992 curriculum includes aims related to teaching, the aims also decreased in number as the learning approach on which the curriculum is based changed (The process of transition to the Cognitive learning approach from the Behavioural learning approach). While the 1992 curriculum included target behaviours, it is observed that the term gains started to be used as of the 2001 curriculum. Therefore, the change in the learning approach that has just been defined is also emphasised. In general, it is also observed that the number of gains decreases. Accordingly, it can be considered that "the less information is more" approach is adopted rather than loading students with too many information. This was already emphasised in the 2005 curriculum.

Upon examining the aims and gains in relation to introducing SPS in the curriculum, it is observed that it is briefly mentioned in the 1992 curriculum, while specifically emphasised, and even given as separate aims in the 2001, 2005, 2013 and 2017 curricula.

Upon examining the vision of the curricula, no clear definition was made on this subject in 1992, but the target of fulfilling the 8-year basic education was emphasised. As of 2001, the general definitions of the vision and 7 -item objectives to be reached were included. The definition of vision with one sentence expressions is also encountered in the science curricula of 2005 and 2013. Since the importance attributed to technology teaching in the age of technology that developed with the inclusion of the term science literacy in the curriculum in 2005 was emphasised, the name of the subject was changed in addition to defining its vision as "Raising all students as science and technology literate regardless of their individual differences". In 2013, both the word technology was removed from the name of the subject, and the definition was given as "Raising all students as science literate individuals" by removing it from the vision. This was also emphasised in the study conducted by Karatay et al. (2013, p. 255). In this sense, it can be said that science literacy is emphasised more in the recent 2 curricula. No determination was made regarding the vision in the latest curriculum that started to be implemented in 2017, but the expression "The Science Course Curriculum that aims to raise all individuals as science literate" before defining the general aims was included (MNE, 2017, p. 5). As can be seen, no emphasis was made on technology in this curriculum, as well.

In the last sub-dimension related to the aims of the curriculum, whether the curriculum includes "Atatürk's Reforms and Atatürk Nationalism", which is the 7th of 14 main principles that make up Article 1 of the General 
aims of Turkish National Education and are listed among the Main principles of Turkish National Education No. 1739 (published in the official gazette of 1973 No. 14574) was also investigated. As it is known, the curricula of the subjects should be in full compliance with the General aims of Turkish National Education. Therefore, it was found out that no association was made with Atatürk's principles that are supposed to be included among the general aims of the curricula of all educational levels in the curricula of 1992 and 2013. Nevertheless, it is observed that they are included in the curricula of 2001 and 2005, and even associations are made with the subjects. There is also not much association in the curriculum of 2017. However, reference was made in only one unit as it is also emphasised in the table above.

Consequently, it can be said that there are differences between the five curricula in terms of the first element of the curriculum.

\subsection{Content Element of the Curriculum}

The information on the Content (scope, approach, and the subject areas included), which is the second element of the curriculum, is presented in Table 2.

Table 2. Differences in relation to the content element of the science curricula

\begin{tabular}{|c|c|c|c|c|c|}
\hline & $\begin{array}{l}\text { Curriculum of } \\
1992\end{array}$ & $\begin{array}{l}\text { Curriculum of } \\
2001\end{array}$ & $\begin{array}{l}\text { Curriculum of } \\
2005\end{array}$ & $\begin{array}{l}\text { Curriculum of } \\
2013 \\
\end{array}$ & $\begin{array}{l}\text { Curriculum of } \\
2017\end{array}$ \\
\hline 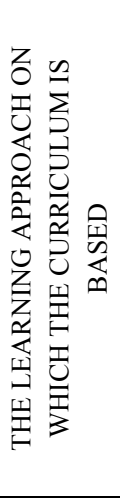 & $\begin{array}{l}\text { Upon examining the } \\
\text { Aim and Behaviour } \\
\text { expressions in the } \\
\text { curriculum, it is } \\
\text { observed that the } \\
\text { curriculum was } \\
\text { prepared based on } \\
\text { "The Behavioural } \\
\text { learning theory". }\end{array}$ & $\begin{array}{l}\text { When the Aim and } \\
\text { Achievement } \\
\text { expressions in the } \\
\text { curriculum are } \\
\text { examined, it is } \\
\text { observed that the } \\
\text { curriculum was } \\
\text { prepared based on } \\
\text { the "Cognitive } \\
\text { learning theory". } \\
\text { However, problems } \\
\text { were encountered in } \\
\text { implementation. }\end{array}$ & $\begin{array}{l}\text { It was endeavoured to } \\
\text { reflect the } \\
\text { Constructivist learning } \\
\text { approach as much as } \\
\text { possible. }\end{array}$ & $\begin{array}{l}\text { The expression } \\
\text { "Research-inquiry } \\
\text { based learning } \\
\text { approach is based on" } \\
\text { is used in the } \\
\text { curriculum (2013, p. } \\
\text { III). No other approach } \\
\text { was included. }\end{array}$ & $\begin{array}{l}\text { The expression } \\
\text { "Research-inquiry based } \\
\text { learning approach with an } \\
\text { interdisciplinary approach } \\
\text { is based on" is used in the } \\
\text { curriculum (2017, p. 11). } \\
\text { No other approach was } \\
\text { included. }\end{array}$ \\
\hline 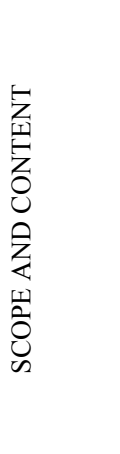 & $\begin{array}{l}\text { Each grade covers } 8 \\
\text { units in the } \\
\text { curriculum, and the } \\
\text { scope of the units is } \\
\text { quite wide, and it } \\
\text { was estimated to } \\
\text { give much } \\
\text { information. }\end{array}$ & $\begin{array}{l}\text { Each grade has } 4 \\
\text { units. } \\
\text { The units were } \\
\text { structured based on } \\
\text { experiments. }\end{array}$ & $\begin{array}{l}\text { Each grade has } 7 \text { units } \\
\text { in the curriculum. } \\
\text { It was tried to cover } \\
\text { more activities within } \\
\text { unit subjects. }\end{array}$ & $\begin{array}{l}\text { Each grade has } 7 \text { units } \\
\text { in the curriculum. } \\
\text { The scope of the units } \\
\text { is not broad, and the } \\
\text { notion less information } \\
\text { is better was adopted. }\end{array}$ & $\begin{array}{l}\text { There are } 7 \text { units in 3rd } \\
\text { grade and } 8 \text { units in 4th } \\
\text { grade in the curriculum. } \\
\text { This new unit added to the } \\
\text { 4th grade is the "Applied } \\
\text { science" unit that will also } \\
\text { continue in the 5th, 6th, 7th } \\
\text { and 8th grades. } \\
\text { The scope of the units is } \\
\text { not broad, and the notion } \\
\text { less information is better } \\
\text { was adopted. }\end{array}$ \\
\hline
\end{tabular}




\begin{tabular}{|c|c|c|c|c|c|}
\hline 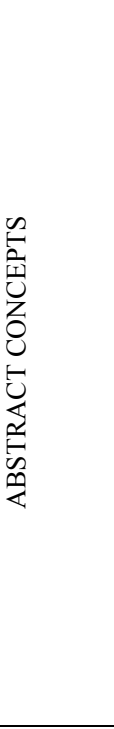 & $\begin{array}{l}\text { It was tried to } \\
\text { classify them, but no } \\
\text { precise orientation } \\
\text { was made in this } \\
\text { respect. } \\
\text { However, the } \\
\text { subject of heat was } \\
\text { first given in 5th } \\
\text { grade, and then it } \\
\text { was provided for to } \\
\text { teach in a more } \\
\text { detailed way in } 7 \text { th } \\
\text { grade since it has } \\
\text { abstract concepts } \\
\text { (1992, pp. } 71-72 \text { ). } \\
\text { The subject of heat } \\
\text { was not addressed in } \\
\text { any other grade. }\end{array}$ & $\begin{array}{l}\text { The curriculum } \\
\text { includes subjects } \\
\text { related to the Earth, } \\
\text { space and the } \\
\text { environment in } \\
\text { addition to the } \\
\text { subjects of physics, } \\
\text { chemistry and } \\
\text { biology. } \\
\text { The subjects were } \\
\text { distributed in a } \\
\text { balanced way to } \\
\text { science fields and } \\
\text { classes, and the level } \\
\text { of the subjects was } \\
\text { defined in } \\
\text { accordance with the } \\
\text { age of students } \\
\text { (2000, p. 1004). }\end{array}$ & $\begin{array}{l}\text { It was shown that the } \\
\text { abstract concepts } \\
\text { would be explained by } \\
\text { being concretized in } \\
\text { given activity } \\
\text { examples. } \\
\text { However, if we } \\
\text { address them in terms } \\
\text { of time, it can be } \\
\text { thought that it can be } \\
\text { hard to provide } \\
\text { sufficient time for } \\
\text { these activities. }\end{array}$ & $\begin{array}{l}\text { Abstract concepts } \\
\text { were not covered } \\
\text { much by the } \\
\text { curriculum. } \\
\text { The subject of light is } \\
\text { covered in 3rd and 4th } \\
\text { grades. }\end{array}$ & $\begin{array}{l}\text { Abstract concepts are not } \\
\text { included in the curriculum. } \\
\text { It is observed that the } \\
\text { contents of physical events } \\
\text { are tried to be given once } \\
\text { in two years briefly and to } \\
\text { the point. }\end{array}$ \\
\hline 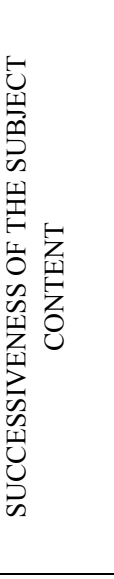 & $\begin{array}{l}\text { While certain } \\
\text { subjects are taught } \\
\text { only in 4th and 5th } \\
\text { grades (Our Earth } \\
\text { and sky-4th grade, } \\
\text { Heat-5th grade, } \\
\text { Sound-5th grade), it } \\
\text { is observed that } \\
\text { other subjects are } \\
\text { taught at both grade } \\
\text { levels. And they are } \\
\text { organized in a way } \\
\text { that they } \\
\text { complement one } \\
\text { another. }\end{array}$ & $\begin{array}{l}\text { No information is } \\
\text { given on this subject } \\
\text { in the introduction } \\
\text { part of the } \\
\text { curriculum. } \\
\text { However, it is } \\
\text { observed that certain } \\
\text { units complement } \\
\text { one another } \\
(2000, \text { p. 1014). }\end{array}$ & $\begin{array}{l}\text { When their content is } \\
\text { examined in general, it } \\
\text { can be said that the } \\
\text { subjects are organized } \\
\text { in a way that they } \\
\text { complement one } \\
\text { another. } \\
\text { It can be said that the } \\
\text { spiral structure } \\
\text { suggested in the } \\
\text { curriculum is } \\
\text { implemented. }\end{array}$ & $\begin{array}{l}\text { When we look at the } \\
\text { subjects of the 3rd and } \\
\text { 4th grades, a spiral } \\
\text { structure in which the } \\
\text { content in the 3rd } \\
\text { grade is taught by } \\
\text { being expanded in the } \\
\text { 4th grade draws } \\
\text { attention. } \\
\text { The subjects are } \\
\text { arranged in a way that } \\
\text { they complement one } \\
\text { another. }\end{array}$ & $\begin{array}{l}\text { In general, subject contents } \\
\text { complement one another. } \\
\text { However, disconnection is } \\
\text { observed in the subject } \\
\text { field of the Living beings } \\
\text { and life. While the 3rd } \\
\text { grade covers the unit "Our } \\
\text { five senses", the unit "Our } \\
\text { food" is included in the 4th } \\
\text { grade, the subject content } \\
\text { is skipped in the } 5 \text { th grade, } \\
\text { and the Systems are } \\
\text { covered in the 6th grade. }\end{array}$ \\
\hline 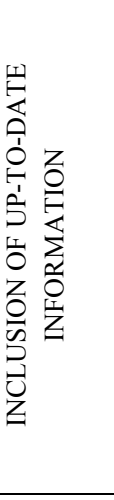 & $\begin{array}{l}\text { Although subjects } \\
\text { include explanations } \\
\text { on the association } \\
\text { with daily life, it is } \\
\text { observed that } \\
\text { contemporary and } \\
\text { new information is } \\
\text { not covered much } \\
\text { (lower grades do not } \\
\text { include it, 7th and } \\
\text { 8th grades include it } \\
\text { partially). }\end{array}$ & $\begin{array}{l}\text { Subjects include } \\
\text { explanations on } \\
\text { making associations } \\
\text { with daily life. For } \\
\text { example; the subject } \\
\text { of earthquakes is } \\
\text { covered by the } \\
\text { 4th-grade's 4th unit, } \\
\text { while no } \\
\text { information is given } \\
\text { on the earthquake of } \\
\text { 1997. } \\
(2000, \text { p. 1027) }\end{array}$ & $\begin{array}{l}\text { In the overview part of } \\
\text { the units, it was stated } \\
\text { that it was necessary } \\
\text { to make an association } \\
\text { with the daily life } \\
\text { when presenting } \\
\text { subjects to students. } \\
\text { The subjects are given } \\
\text { by making an } \\
\text { association with the } \\
\text { daily life in the } \\
\text { activity examples } \\
\text { prepared. }\end{array}$ & $\begin{array}{l}\text { Both importance was } \\
\text { attributed to making } \\
\text { associations between } \\
\text { the subjects and the } \\
\text { daily life (Aim 6), and } \\
\text { the contemporary } \\
\text { subjects were included } \\
\text { in the curriculum. }\end{array}$ & $\begin{array}{l}\text { The association of the } \\
\text { subjects with the daily life } \\
\text { was included in the } \\
\text { curriculum (Aim 4). } \\
\text { Moreover, defining and } \\
\text { seeking a solution to a } \\
\text { daily life problem are } \\
\text { emphasised in the } \\
\text { "Applied science" unit that } \\
\text { is recently added to the 4th } \\
\text { grade. }\end{array}$ \\
\hline 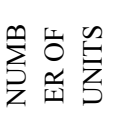 & $\begin{array}{l}\text { 4th grade: } 8 \text { units } \\
\text { 5th grade: } 8 \text { units }\end{array}$ & $\begin{array}{l}\text { 4th grade: } 4 \text { units } \\
\text { 5th grade: } 4 \text { units }\end{array}$ & $\begin{array}{l}\text { 4th grade: } 7 \text { units } \\
\text { 5th grade: } 7 \text { units }\end{array}$ & $\begin{array}{l}\text { 3rd grade: } 7 \text { units } \\
\text { 4th grade: } 7 \text { units }\end{array}$ & $\begin{array}{l}\text { 3rd grade: } 7 \text { units } \\
\text { 4th grade: } 8 \text { units }\end{array}$ \\
\hline
\end{tabular}




\begin{tabular}{|c|c|c|c|c|c|}
\hline 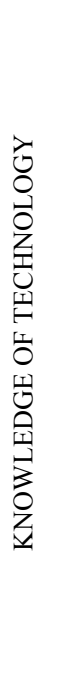 & $\begin{array}{l}\text { Technology is } \\
\text { referred to and is } \\
\text { said to be important } \\
\text { in the Introduction } \\
\text { part of the } \\
\text { curriculum (1992, } \\
\text { pp. 8-9). However, } \\
\text { information on } \\
\text { technology and } \\
\text { contemporary is } \\
\text { developments } \\
\text { generally addressed } \\
\text { in 6th, 7th and 8th } \\
\text { grades. }\end{array}$ & $\begin{array}{l}\text { Technology is } \\
\text { referred to and is } \\
\text { said to be important } \\
\text { in the Introduction } \\
\text { part of the } \\
\text { curriculum (2000, p. } \\
\text { 1001). Regarding } \\
\text { technology and } \\
\text { contemporary } \\
\text { developments (in } \\
\text { 4th grade), it was } \\
\text { explained that it is } \\
\text { now possible to split } \\
\text { the atom. }\end{array}$ & $\begin{array}{l}\text { In the curriculum, it } \\
\text { was tried to be shown } \\
\text { how important } \\
\text { technology learning is } \\
\text { in Science- } \\
\text { Technology-Society- } \\
\text { Environment Relations } \\
\text { that are among the } \\
\text { dimensions of science } \\
\text { and technology } \\
\text { literacy (2008, pp. } \\
\text { 1033-1034, 1037). } \\
\text { Moreover, it is shown } \\
\text { that science and } \\
\text { technology are } \\
\text { concentric in STSE } \\
\text { gains and activity } \\
\text { examples. }\end{array}$ & $\begin{array}{l}\text { Technology is } \\
\text { attributed importance } \\
\text { in the curriculum. } \\
\text { There is a learning } \\
\text { area called } \\
\text { Science-Technology- } \\
\text { Society-Environment. } \\
\text { Moreover, there are } \\
\text { subjects such as } \\
\text { Lighting Technology, } \\
\text { Sound Technologies in } \\
\text { the curriculum. }\end{array}$ & $\begin{array}{l}\text { It is observed that } \\
\text { technology is not } \\
\text { mentioned much in the } \\
\text { curriculum. It is not } \\
\text { mentioned in the general } \\
\text { aims. It is observed that } \\
\text { innovative inventions and } \\
\text { technology are addressed } \\
\text { only within Science and } \\
\text { engineering practices. } \\
\text { The curriculum covers the } \\
\text { subject of "Lightning and } \\
\text { Sound Technologies" in } \\
\text { the 4th grade. }\end{array}$ \\
\hline 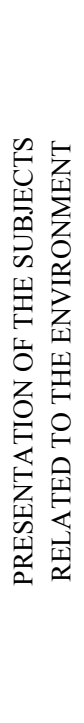 & $\begin{array}{l}\text { A general } \\
\text { explanation is made } \\
\text { about the } \\
\text { Environment and } \\
\text { environmental } \\
\text { consciousness in the } \\
\text { introduction part of } \\
\text { the curriculum } \\
\text { (1992, p. 8). } \\
\text { Moreover, as can be } \\
\text { seen in the attached } \\
\text { table, the "Human } \\
\text { and environment" } \\
\text { unit is included at all } \\
\text { grade levels. }\end{array}$ & $\begin{array}{l}\text { The unit "Let's Get } \\
\text { to Know Our } \\
\text { Environment" is } \\
\text { included at the 4th } \\
\text { grade level. The } \\
\text { investigation of } \\
\text { air-water-soil } \\
\text { pollution and their } \\
\text { solutions was } \\
\text { mentioned in the } \\
\text { unit "Nature of the } \\
\text { Matter" of 4th } \\
\text { Grade's Unit 2. } \\
\text { And the Unit } \\
\text { "Living Beings and } \\
\text { Their Interaction } \\
\text { with the Nature" is } \\
\text { in the 5th grade } \\
\text { (2000, p. 1031). }\end{array}$ & $\begin{array}{l}\text { In the curriculum, the } \\
\text { gains for "Science- } \\
\text { Technology-Society- } \\
\text { Environment" for the } \\
\text { 4th and 5th grades are } \\
\text { presented in a table } \\
\text { (2004, p. 1037). } \\
\text { Furthermore, gains } \\
\text { related to the } \\
\text { environment are given } \\
\text { in } 5 \text { units }(2,4,5,6,7) \text { in } \\
\text { the 4th grade and } 3 \\
\text { units }(2,6,7) \text { in the } \\
5 \text { th grade }\end{array}$ & $\begin{array}{l}\text { Items regarding the } \\
\text { environment and } \\
\text { environmental } \\
\text { consciousness are } \\
\text { included in the general } \\
\text { aims of the curriculum } \\
\text { (aim } 2 \text { and aim 4). } \\
\text { Moreover, the 3rd } \\
\text { grade includes the } \\
\text { subject "Natural and } \\
\text { Artificial } \\
\text { Environment" (2013, } \\
\text { p. 4). The subject } \\
\text { "Human and } \\
\text { Environment } \\
\text { Relationship" is also } \\
\text { mentioned in the 4th } \\
\text { grade (2013, p. 13). }\end{array}$ & $\begin{array}{l}\text {-Subjects related to the } \\
\text { environment are included } \\
\text { in the general aims of the } \\
\text { curriculum (aims 1,2, } 3 \\
\text { and 7). } \\
\text { The 3rd grade includes the } \\
\text { subject "A journey into the } \\
\text { world of living beings", } \\
\text { and the 4th grade includes } \\
\text { the subject "Human and } \\
\text { Environment". (2017, p. } \\
\text { 13) }\end{array}$ \\
\hline
\end{tabular}




\begin{tabular}{|c|c|c|c|c|c|}
\hline 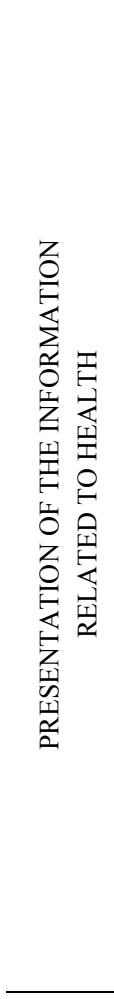 & $\begin{array}{l}\text { It is observed that } \\
\text { information about } \\
\text { human health is } \\
\text { given in different } \\
\text { units at all grade } \\
\text { levels. These are as } \\
\text { follows: } \\
\text { In 4th grade; } \\
\text { Unit 2- Living } \\
\text { beings and life. } \\
\text { Unit 4- Human and } \\
\text { environment (1992, } \\
\text { pp. 88-92). } \\
\text { In 5th Grade; } \\
\text { Unit 1- Let's get to } \\
\text { know our body, } \\
\text { Unit 3- Human and } \\
\text { environment, } \\
\text { Unit 5- Sound, } \\
\text { Unit 6- Light, } \\
\text { Unit 7- Heat, (1992, } \\
\text { pp. 100-117). }\end{array}$ & $\begin{array}{l}\text { In 5th grade; } \\
\text { "Living Beings and } \\
\text { Their Interaction } \\
\text { with Nature"; } \\
\text { viruses that cause } \\
\text { diseases by affecting } \\
\text { human health } \\
\text { negatively, and the } \\
\text { effects of bacteria } \\
\text { on human health } \\
(2000, \\
1030-1031) \text {. pp. }\end{array}$ & $\begin{array}{l}\text { Information on health } \\
\text { is given in the } \\
\text { Inter-Discipline Area } \\
\text { Gains Table matching } \\
\text { with the 4th and 5th } \\
\text { grade Science and } \\
\text { Technology Course } \\
\text { Curriculum Gains } \\
\text { (2008, pp. 1076-1109). } \\
\text { The Health culture } \\
\text { gains in the table are } \\
\text { correlated with the } \\
\text { units 1, 4, 5, } 6 \text { and } 7 \text { in } \\
\text { the 4th grade. } \\
\text { For example; } \\
\text { 4th-grade Unit } 1 \\
\text { Living Beings and } \\
\text { Life, } \\
\text { In the 5th grade, it is } \\
\text { correlated with the } \\
\text { units } 1,4 \text { and } 6 .\end{array}$ & $\begin{array}{l}\text { It is mentioned that } \\
\text { basic information on } \\
\text { health will be given in } \\
\text { the general aims part } \\
\text { of the curriculum (aim } \\
\text { 1). } \\
\text { Also, information on } \\
\text { human health is } \\
\text { included among the } \\
\text { subjects. } \\
\text { These are as follows: } \\
\text { 1-3rd grades; } \\
\text { Unit 5- Living Beings } \\
\text { and Life, (2013, p. 5). } \\
\text { 2- 4th grades; } \\
\text { Unit 1- Let's Get to } \\
\text { Know our Body, } \\
\text { (2013, p. 8). } \\
\text { Unit 4- Lightning and } \\
\text { Sound Technologies } \\
\text { from Past to Present, } \\
\text { (2013, p. 12). } \\
\text { Unit 5-Microscopic } \\
\text { Creatures } \\
\text { Environment, (2013, and } \\
\text { p. 13). }\end{array}$ & $\begin{array}{l}\text { No reference is made to } \\
\text { health in the general aims } \\
\text { part of the curriculum. } \\
\text { Information on human } \\
\text { health is included under } \\
\text { certain subjects. } \\
\text { "Our five senses" unit in } \\
\text { the 3rd grade addresses the } \\
\text { health of our sensory } \\
\text { organs (2017, p. 16), while } \\
\text { the unit "Our Food" in the } \\
4 \text { th grade talks about the } \\
\text { effects of nutrition, and the } \\
\text { use of alcohol, cigarette, } \\
\text { etc. on human health } \\
\text { (2017, p. 21). Moreover, } \\
\text { the effects of noise } \\
\text { pollution on health are } \\
\text { included in the "Lightning } \\
\text { technologies" unit in the } \\
4 \text { th grade (2017, p. 23). }\end{array}$ \\
\hline
\end{tabular}

If we look at the learning approaches on which the curricula are based first, a transition from the behavioural approach to the research-inquiry approach is observed. We can observe that the student is regarded as a person that takes information as it is and reflects it into his/her behaviour in the 1992 curriculum, but an effort is shown to ensure a transition to a cognitive (constructivist) approach that defends that an individual structures information in his/her mind. However, as it is also emphasised by the MNE in the 2004 draft science curriculum, it is determined that this transition, unfortunately, cannot be fully ensured (MNE, 2004, p. 39). While no approach is directly referred to in the curricula of 2013 and 2017, it is stated that activities are planned according to the learning approach that is based on the student-centred research and inquiry (the constructivist approach). Karatay et al. (2013, p. 255) specifically emphasised this change in the curriculum of 2013.

Again, upon evaluating in terms of scope and content, a change is observed from the curriculum of 1992 to the curriculum of 2017, the scope becomes narrower and becomes more activity-based. When we examine the succession of the subject content, it can be said that the subjects are generally arranged in a way that they complement one another in all curricula. However, it can be said that the succession in all subjects cannot be ensured by decreasing the number of the units in the curriculum of 2001 (see Table 3 for additional information). The differences between the curricula also attract attention in terms of the time allocated to the units. A new learning domain was added to the lesson starting from the 4th grades in the curriculum of 2017. It is observed that the "Applied Science" unit is added to the sub-domain of "Science and engineering practices" as a skill learning domain to each grade (4th, 5th, 6th, 7th and 8th grades). This addition can be considered as a beginning of the STEM (Science, Technology, Engineering and Mathematics) approach. Therefore, it can be said that creativity and innovation are added to science lessons. Consequently, while there are 7 units in the 3rd grade, this number increases to 8 in the 4 th grade. This subject was introduced as the last unit in all grades, and it was stated that students are expected to use their innovative process skills such as getting to know a problem, looking for a solution and creating a product "in cooperation with their friends" under the supervision of their teacher.

Upon addressing the learning domains, while the curriculum of 1992 includes only the information areas, no explanation was made on this subject in 2001. As of 2005, it is observed that SPS and affective and skill areas are also added. Differences are also observed in the associations made with other lessons in the curricula. While associations with other fields were not included in the curricula of 1992, 2001 and 2013, they were included in the curriculum of 2005. The Turkey Qualifications Framework (TQF) was referred to in the curriculum of 2017, and it was provided for that gains cover these skills. 
"The TQF is the national qualifications framework that is designed in line with the European Qualifications Framework (EQF) and shows all qualification principles gained through vocational, general and academic curricula and syllabi and other ways of learning, including the primary, secondary and higher education. The main aim of the TQF is to provide an integrated structure in which all the qualifications in our country are defined, classified, and consequently, relations such as the transfer and advancement between the qualifications are defined. The TQF includes eight key competencies that all individuals are expected to gain within the scope of lifelong learning.

These are listed as the communication in the mother tongue, communication in foreign languages, mathematical competence and basic competencies in science/technology, digital competence, learning how to learn, social competence and competencies related to citizenship, taking initiatives and the sense of entrepreneurship, cultural awareness and expression.

All the key competencies are of the same importance because each of them may contribute to a successful life in an information society. Most of these competencies are in accord with one another, comprise each other, and are based on the principle of supporting one another." (MNE, 2017, p. 6)",

It was also emphasised that these competencies are related to the gains prepared in a way that they cover the Scientific Process Skills (SPS), Life skills and Engineering and design skills included in the curriculum.

Although technology was mentioned in the introduction parts of the 1992 and 2001 curricula, it was given significant importance as a requirement of the modern society as of the curriculum of 2005 , and as can also be realized from the change in the name of this course-it was said that science and technology are concentric. While there is also a similar case in the curriculum of 2013 (the STSE area is also included in the content, although technology is removed from its name), it is not included much in the curriculum of 2017.

The fact that subjects related to the environment and health are attached importance in all curricula draws attention. However, it is observed that information on health is given only in one grade and one unit as a result of the decrease in the number of units in the 2001 curriculum. As for the 2017 curriculum, it is observed that information on healthy and balanced diet, obesity, storage and freshness of food, frozen foods, etc. is addressed in the unit Our Foods in 4th grade. It can be said that this is positive in that it ensures drawing attention to the nutrition problems in our age.

Consequently, it can be said that there are differences between the five curricula in terms of "content", which is the second element of the curriculum. More detailed explanation on the number of units of the curricula is presented in Table 3.

Table 3. Unit names in the science curricula

\begin{tabular}{|c|c|c|c|c|c|c|c|c|c|}
\hline \multicolumn{2}{|l|}{$\begin{array}{l}1992 \text { Science } \\
\text { Curriculum }\end{array}$} & \multicolumn{2}{|c|}{$\begin{array}{l}2001 \text { Science } \\
\text { Curriculum }\end{array}$} & \multicolumn{2}{|c|}{$\begin{array}{l}2005 \text { Science } \\
\text { Curriculum }\end{array}$} & \multicolumn{2}{|l|}{$\begin{array}{l}2013 \text { Science } \\
\text { Curriculum }\end{array}$} & \multicolumn{2}{|l|}{$\begin{array}{l}2017 \text { Science } \\
\text { Curriculum }\end{array}$} \\
\hline 4th Grade & $\begin{array}{l}\text { th } \\
\text { Grade } \\
\end{array}$ & $\begin{array}{l}\text { 4th } \\
\text { Grade }\end{array}$ & 5th Grade & 4th Grade & 5th Grade & 3rd Grade & 4th Grade & 3rd Grade & 4th Grade \\
\hline $\begin{array}{l}\text { Our Earth and } \\
\text { the sky }\end{array}$ & $\begin{array}{l}\text { Let's get } \\
\text { to know } \\
\text { our body }\end{array}$ & $\begin{array}{l}\text { Let's get } \\
\text { to know } \\
\text { our } \\
\text { environ- } \\
\text { ment }\end{array}$ & $\begin{array}{l}\text { Interaction } \\
\text { between } \\
\text { Living } \\
\text { Beings and } \\
\text { Nature }\end{array}$ & $\begin{array}{l}\text { Let's } \\
\text { Solve the } \\
\text { Puzzle of } \\
\text { Our Body }\end{array}$ & $\begin{array}{l}\text { Let's } \\
\text { Solve the } \\
\text { Puzzle of } \\
\text { Our Body }\end{array}$ & $\begin{array}{l}\text { Our Five } \\
\text { Senses }\end{array}$ & $\begin{array}{l}\text { Let's Solve } \\
\text { the Puzzle of } \\
\text { Our Body }\end{array}$ & $\begin{array}{l}\text { Let's Get } \\
\text { to Know } \\
\text { Our } \\
\text { Planet }\end{array}$ & $\begin{array}{l}\text { Earth crust } \\
\text { and the } \\
\text { Movements } \\
\text { of Our Earth }\end{array}$ \\
\hline $\begin{array}{l}\text { Living beings } \\
\text { and life }\end{array}$ & $\begin{array}{l}\text { Diversity } \\
\text { of living } \\
\text { beings }\end{array}$ & $\begin{array}{l}\text { Nature of } \\
\text { the } \\
\text { Matter }\end{array}$ & $\begin{array}{l}\text { Sound and } \\
\text { Light }\end{array}$ & $\begin{array}{l}\text { Let's Get } \\
\text { to Know } \\
\text { the Matter }\end{array}$ & $\begin{array}{l}\text { Change } \\
\text { and } \\
\text { Recognit- } \\
\text { ion of the } \\
\text { Matter }\end{array}$ & $\begin{array}{l}\text { Let's Get to } \\
\text { Know the } \\
\text { Force }\end{array}$ & $\begin{array}{l}\text { Effects of the } \\
\text { Force }\end{array}$ & $\begin{array}{l}\text { Our Five } \\
\text { Senses }\end{array}$ & Our Food \\
\hline $\begin{array}{l}\text { Diversity of } \\
\text { Living Beings }\end{array}$ & $\begin{array}{l}\text { Human } \\
\text { and } \\
\text { environ- } \\
\text { ment }\end{array}$ & $\begin{array}{l}\text { Living } \\
\text { Beings } \\
\text { are } \\
\text { Diverse }\end{array}$ & $\begin{array}{l}\text { Heat and the } \\
\text { Journey of } \\
\text { Heat in the } \\
\text { Matter }\end{array}$ & $\begin{array}{l}\text { Force and } \\
\text { Movement }\end{array}$ & $\begin{array}{l}\text { Force and } \\
\text { Moveme- } \\
\text { nt }\end{array}$ & $\begin{array}{l}\text { Let's Get to } \\
\text { Know the } \\
\text { Matter }\end{array}$ & $\begin{array}{l}\text { Let's Get to } \\
\text { Know the } \\
\text { Matter }\end{array}$ & $\begin{array}{l}\text { Let's Get } \\
\text { to Know } \\
\text { the Force }\end{array}$ & $\begin{array}{l}\text { Effects of } \\
\text { Force }\end{array}$ \\
\hline $\begin{array}{l}\text { Human and } \\
\text { environment }\end{array}$ & $\begin{array}{l}\text { Matter } \\
\text { and } \\
\text { energy }\end{array}$ & $\begin{array}{l}\text { Our } \\
\text { planet }\end{array}$ & $\begin{array}{l}\text { Movement } \\
\text { and Force }\end{array}$ & $\begin{array}{l}\text { Light and } \\
\text { Sound }\end{array}$ & $\begin{array}{l}\text { Electricity } \\
\text { in Our } \\
\text { Life }\end{array}$ & $\begin{array}{l}\text { Light and } \\
\text { Sounds in } \\
\text { our } \\
\text { Environme- } \\
\text { nt }\end{array}$ & $\begin{array}{l}\text { Lightning and } \\
\text { Sound } \\
\text { Technologies } \\
\text { from Past to } \\
\text { Present }\end{array}$ & $\begin{array}{l}\text { Let's Get } \\
\text { to Know } \\
\text { the Matter }\end{array}$ & $\begin{array}{l}\text { Properties of } \\
\text { the Matter }\end{array}$ \\
\hline
\end{tabular}




\begin{tabular}{|c|c|c|c|c|c|c|c|c|}
\hline $\begin{array}{l}\text { Getting } \\
\text { Know tl } \\
\text { Matter }\end{array}$ & $\begin{array}{l}\text { to } \\
\text { the }\end{array}$ & Sound & $\begin{array}{l}\text { Our Planet } \\
\text { Earth }\end{array}$ & $\begin{array}{l}\text { Earth, } \\
\text { Sun and } \\
\text { Moon }\end{array}$ & $\begin{array}{l}\text { Journey } \\
\text { into the } \\
\text { Life of } \\
\text { Living } \\
\text { Beings }\end{array}$ & $\begin{array}{l}\text { Microscopic } \\
\text { Creatures and } \\
\text { Our } \\
\text { Environment }\end{array}$ & $\begin{array}{l}\text { Light and } \\
\text { Sounds in } \\
\text { Our } \\
\text { Environ- } \\
\text { ment }\end{array}$ & $\begin{array}{l}\text { Lightning } \\
\text { and Sound } \\
\text { Technologi- } \\
\text { es }\end{array}$ \\
\hline Light & & Light & $\begin{array}{l}\text { Let's } \\
\text { Travel } \\
\text { around, } \\
\text { Get to } \\
\text { Know the } \\
\text { World of } \\
\text { Living } \\
\text { Beings }\end{array}$ & $\begin{array}{l}\text { Let's } \\
\text { Travel } \\
\text { around, } \\
\text { Get to } \\
\text { Know the } \\
\text { World of } \\
\text { Living } \\
\text { Beings }\end{array}$ & $\begin{array}{l}\text { Electrical } \\
\text { Tools in } \\
\text { Our Life }\end{array}$ & $\begin{array}{l}\text { Simple } \\
\text { Electrical } \\
\text { Circuits }\end{array}$ & $\begin{array}{l}\text { Journey } \\
\text { into the } \\
\text { Life of } \\
\text { Living } \\
\text { Beings }\end{array}$ & $\begin{array}{l}\text { Human and } \\
\text { Environment }\end{array}$ \\
\hline Electricity & & Heat & $\begin{array}{l}\text { Electricity } \\
\text { in Our } \\
\text { Life }\end{array}$ & $\begin{array}{l}\text { Light and } \\
\text { Sound }\end{array}$ & $\begin{array}{l}\text { Let's Get to } \\
\text { Know Our } \\
\text { Planet }\end{array}$ & $\begin{array}{l}\text { Movements of } \\
\text { Our Earth }\end{array}$ & $\begin{array}{l}\text { Electrical } \\
\text { Tools }\end{array}$ & $\begin{array}{l}\text { Simple } \\
\text { Electrical } \\
\text { Circuits }\end{array}$ \\
\hline Energy & & $\begin{array}{l}\text { Electrici- } \\
\text { ty }\end{array}$ & & & & & & $\begin{array}{l}\text { Applied } \\
\text { Science }\end{array}$ \\
\hline
\end{tabular}

\subsection{Educational Status Element (Learning-Teaching Process) of the Curriculum}

Information on the Educational Status (Learning-teaching process) element, which is the third element of the curriculum, is presented in Table 4 below.

Table 4. Differences in relation to the educational status element (learning-teaching process) of the science curricula

\begin{tabular}{|c|c|c|c|c|c|}
\hline & Curriculum of 1992 & Curriculum of 2001 & Curriculum of 2005 & Curriculum of 2013 & Curriculum of 2017 \\
\hline 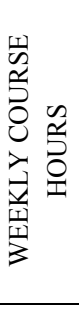 & $\begin{array}{l}\text { It was planned as } 4 \\
\text { hours a week. } \\
\text { However, the course } \\
\text { hours were reduced to } \\
3 \text { with the transition to } \\
\text { the 8-year Basic } \\
\text { education in } \\
1997 / 1998 \text {. }\end{array}$ & $\begin{array}{l}\text { It was planned as } 3 \\
\text { hours a week. }\end{array}$ & $\begin{array}{l}\text { It was planned as } 4 \text { hours } \\
\text { a week. }\end{array}$ & $\begin{array}{l}\text { It was planned as } 3 \text { hours } \\
\text { a week. }\end{array}$ & $\begin{array}{l}\text { It was planned as } 3 \text { hours } \\
\text { a week. }\end{array}$ \\
\hline 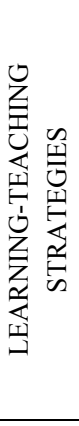 & $\begin{array}{l}\text { There is no general } \\
\text { explanation for the } \\
\text { learning and teaching } \\
\text { strategies to be used in } \\
\text { the curriculum. }\end{array}$ & $\begin{array}{l}\text { There is a title called } \\
\text { learning and teaching } \\
\text { activities in the } \\
\text { curriculum. } \\
\text { Leading students to } \\
\text { the research-discovery } \\
\text { process is mentioned } \\
\text { under this title } \\
(2000, \text { p. 1002). }\end{array}$ & $\begin{array}{l}\text { Teaching strategies were } \\
\text { presented, and teachers } \\
\text { were made free in } \\
\text { choosing their strategies } \\
\text { based on the } \\
\text { constructivist approach } \\
\text { to get the gains in the } \\
\text { curriculum. }\end{array}$ & $\begin{array}{l}\text { Under the title "Adopted } \\
\text { Strategies and Methods" } \\
\text { in the curriculum, it is } \\
\text { mentioned that } \\
\text { classroom and } \\
\text { out-of-school learning } \\
\text { environments will be } \\
\text { designed according to } \\
\text { the "Research-inquiry } \\
\text { based learning strategy" } \\
(2013, \text { p. III) }\end{array}$ & $\begin{array}{l}\text { Under the title "Adopted } \\
\text { Strategies and Methods" } \\
\text { in the curriculum, it is } \\
\text { mentioned that } \\
\text { classroom/school and } \\
\text { out-of-school learning } \\
\text { environments will be } \\
\text { designed according to } \\
\text { the "Research-inquiry } \\
\text { based learning strategy" } \\
\text { (2017, pp. 11-12). }\end{array}$ \\
\hline 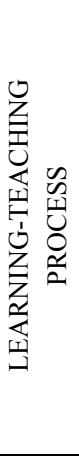 & $\begin{array}{l}\text { Upon examining the } \\
\text { expressions in the } \\
\text { curriculum, it is } \\
\text { observed that a } \\
\text { "Teacher-centred" } \\
\text { learning process is } \\
\text { defined in general. }\end{array}$ & $\begin{array}{l}\text { Upon examining the } \\
\text { expressions in the } \\
\text { curriculum, it is } \\
\text { observed that a } \\
\text { "Student-centred" } \\
\text { learning process is } \\
\text { defined in general. * }\end{array}$ & $\begin{array}{l}\text { A "student-centred" } \\
\text { learning process was } \\
\text { defined since the } \\
\text { curriculum was created } \\
\text { based on the } \\
\text { Constructivist approach. }\end{array}$ & $\begin{array}{l}\text { In the curriculum, a } \\
\text { "student-centred" } \\
\text { learning process, in } \\
\text { which the student is } \\
\text { responsible for his/her } \\
\text { own learning, that allows } \\
\text { for structuring the } \\
\text { information in one's own } \\
\text { mind by ensuring active } \\
\text { participation in the } \\
\text { learning process, is } \\
\text { mentioned (2013, p. III) }\end{array}$ & $\begin{array}{l}\text { In the curriculum, "the } \\
\text { learning process was } \\
\text { defined as covering the } \\
\text { discovery, inquiry, } \\
\text { argument creation and } \\
\text { product design" (2017, } \\
\text { p. 12). The student is } \\
\text { responsible for his/her } \\
\text { own learning; } \\
\text { accordingly, the process } \\
\text { can be named as } \\
\text { student-centred. }\end{array}$ \\
\hline
\end{tabular}




\begin{tabular}{|c|c|c|c|c|c|}
\hline 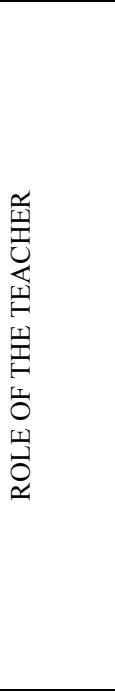 & $\begin{array}{l}\text { The expressions in the } \\
\text { curriculum show that a } \\
\text { "Teacher-centred" } \\
\text { learning process is } \\
\text { adopted. }\end{array}$ & $\begin{array}{l}\text { In the curriculum, } \\
\text { "Expectations from the } \\
\text { Teacher" are those; } \\
\text { "Teachers should } \\
\text { create a suitable } \\
\text { environment for } \\
\text { students to learn by } \\
\text { exploring. They } \\
\text { should be involved in } \\
\text { the process in a more } \\
\text { active way with } \\
\text { students in accordance } \\
\text { with the } \\
\text { student-centred } \\
\text { approach. Students } \\
\text { should be motivated } \\
\text { by teachers." (2000, p. } \\
\text { 1011). }\end{array}$ & $\begin{array}{l}\text { The teacher was defined } \\
\text { as the person who pays } \\
\text { attention to using various } \\
\text { teaching strategies in } \\
\text { accordance with the } \\
\text { constructivist approach, } \\
\text { takes individual } \\
\text { differences into } \\
\text { consideration, guides the } \\
\text { process rather than } \\
\text { manages it. }\end{array}$ & $\begin{array}{l}\text { In the curriculum, the } \\
\text { teacher was defined as } \\
\text { the person who } \\
\text { encourages students to } \\
\text { develop the soul and } \\
\text { sense for researching and } \\
\text { scientific way of } \\
\text { thinking by adopting a } \\
\text { facilitating and guiding } \\
\text { role, and who ensures } \\
\text { that scientific ethical } \\
\text { principles are adopted in } \\
\text { applications (2013, p. } \\
\text { III). }\end{array}$ & $\begin{array}{l}\text { The "encouraging, } \\
\text { guiding roles" of the } \\
\text { teacher are referred to in } \\
\text { the curriculum (2017, p. } \\
11) \text { and creating a } \\
\text { democratic environment } \\
\text { in the classroom, and } \\
\text { helping students to } \\
\text { achieve higher level } \\
\text { thinking, product } \\
\text { development, discovery } \\
\text { and innovation making } \\
\text { levels are addressed } \\
(2017, \text { p. 11). }\end{array}$ \\
\hline 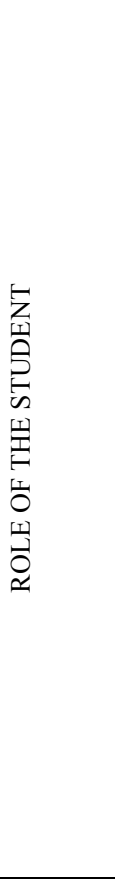 & $\begin{array}{l}\text { Although the } \\
\text { expression that } \\
\text { students should } \\
\text { perform their own } \\
\text { learning was used in } \\
\text { the introduction part of } \\
\text { the curriculum (1992, } \\
\text { pp. 8-9), it is observed } \\
\text { that an overall } \\
\text { teacher-centred } \\
\text { process is defined } \\
\text { when the Aim, } \\
\text { behaviours and } \\
\text { handling parts of the } \\
\text { whole curriculum are } \\
\text { examined. }\end{array}$ & $\begin{array}{l}\text { The role of the student } \\
\text { in the curriculum is } \\
\text { given under the title } \\
\text { "Expectations from } \\
\text { Students". Each } \\
\text { student should be } \\
\text { individually aware of } \\
\text { his/her responsibilities } \\
\text { in science learning. } \\
\text { They should be } \\
\text { interested in the } \\
\text { science lesson, } \\
\text { participate in the } \\
\text { process actively, do } \\
\text { research, discover, and } \\
\text { participate in group } \\
\text { works. They should } \\
\text { learn the rules in the } \\
\text { science course at first, } \\
\text { and act accordingly } \\
\text { (2000, p. 1012). }\end{array}$ & $\begin{array}{l}\text { The student should be } \\
\text { active in the learning } \\
\text { process, questioning, } \\
\text { investigator, and have a } \\
\text { character that actively } \\
\text { participates in } \\
\text { problem-solving and } \\
\text { decision-making } \\
\text { processes. }\end{array}$ & $\begin{array}{l}\text { The role of the student in } \\
\text { the curriculum was } \\
\text { defined as researching, } \\
\text { questioning, explaining } \\
\text { and discussing the } \\
\text { source of information. } \\
\text { It was emphasised that } \\
\text { the student is responsible } \\
\text { for his/her own learning } \\
\text { and participates in the } \\
\text { process actively (2013, } \\
\text { p. III). }\end{array}$ & $\begin{array}{l}\text { In the curriculum, it was } \\
\text { emphasised that "the } \\
\text { student is responsible for } \\
\text { his/her own learning, and } \\
\text { the learning strategy that } \\
\text { is based on } \\
\text { research-inquiry and the } \\
\text { transfer of information in } \\
\text { which their active } \\
\text { participation in the } \\
\text { learning process is } \\
\text { ensured was } \\
\text { emphasised" (2017, p. } \\
\text { 11) in suggested that } \\
\text { It is in } \\
\text { students participate in } \\
\text { the process in formal and } \\
\text { informal learning } \\
\text { environments in their } \\
\text { interaction with } \\
\text { peers under the guidance } \\
\text { of their teacher (2017, p. } \\
12)\end{array}$ \\
\hline 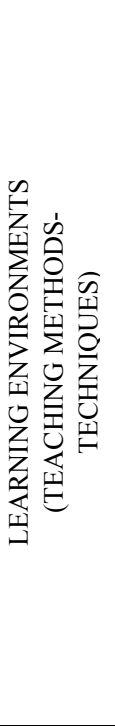 & $\begin{array}{l}\text { Teaching methods and } \\
\text { techniques such as } \\
\text { "Experiment, } \\
\text { Observation, } \\
\text { Assignment, Group } \\
\text { work, Discussion, } \\
\text { Case study, Teaching } \\
\text { through examples, } \\
\text { Lecturing, Teaching } \\
\text { through models, } \\
\text { Demonstration } \\
\text { through diagrams, } \\
\text { Examination of living } \\
\text { beings, Experiment } \\
\text { and model design" } \\
\text { were used. }\end{array}$ & 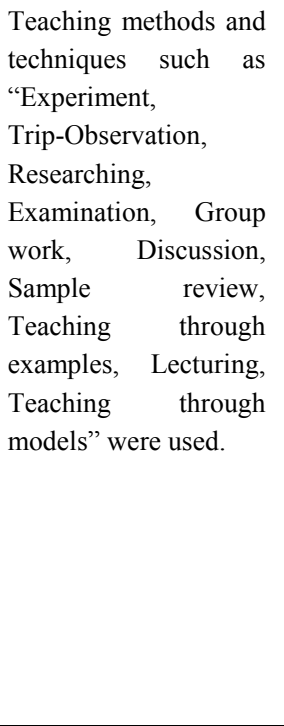 & $\begin{array}{l}\text { Teaching strategies such } \\
\text { as "Narration, } \\
\text { Programmed one-to-one } \\
\text { teaching, Video display, } \\
\text { Simulation, exercising, } \\
\text { Small group discussions } \\
\text { (peer teaching), School } \\
\text { trips, Cooperation-based } \\
\text { learning, Drama, Playing } \\
\text { Games, Library review, } \\
\text { Questioning, Discovery, } \\
\text { Problem-based learning, } \\
\text { Learning centres, } \\
\text { Programmed learning, } \\
\text { Personalized learning } \\
\text { systems" were used. }\end{array}$ & $\begin{array}{l}\text { The classroom and } \\
\text { out-of-school learning } \\
\text { environments were } \\
\text { mentioned in the } \\
\text { curriculum. Methods and } \\
\text { techniques such as } \\
\text { problem, project, } \\
\text { argumentation, } \\
\text { cooperation based } \\
\text { learning, etc. were } \\
\text { emphasised (2013, p. } \\
\text { III). }\end{array}$ & $\begin{array}{l}\text { Classroom/school and } \\
\text { out-of-school learning } \\
\text { environments were } \\
\text { mentioned in the } \\
\text { curriculum. } \\
\text { "Centring on the student } \\
\text { (problem, project, } \\
\text { argumentation, } \\
\text { cooperation-based } \\
\text { learning, etc.)" was } \\
\text { referred to (2017, p. 11). } \\
\text { Moreover, it was } \\
\text { suggested to include } \\
\text { activities such as } \\
\text { designing new products } \\
\text { in the process of learning } \\
\text { and communicating and } \\
\text { discussing ideas with } \\
\text { friends (2017, p. 12). }\end{array}$ \\
\hline
\end{tabular}


When table 4 is examined, it is observed that learning and teaching strategies are addressed under a specific title in all curricula apart from the curriculum of 1992. The learning-teaching process that is teacher-centred in the curriculum of 1992 is student-centred in subsequent curricula, whereas as of 2001, the student-centred approach was adopted, and it was emphasised that the teacher was a guide rather than a director. However, as it was also previously stated (MNE, 2004, p. 39), this transition could not be realized. It is possible to observe the importance attributed especially to the student-centred learning process when the "role of the student" is explained in the curricula of 2005, 2013 and 2017. As can be seen from the table, the fact that the student is active in all these three curricula emphasises that he/she is responsible for his/her own learning.

When learning environments (methods and techniques) are examined, it draws attention that transition from teacher-centred methods to student-centred methods and techniques in which the student is active is realized. Here, it is observed that methods and techniques such as Project, Problem, Cooperation based learning are emphasised. It is observed that importance is attached to argumentation in the 2013 and 2017 curricula. However, the necessity for the competencies to be brought by pre-service teachers from the pre-service learning process, and introducing the process with in-service learning opportunities is revealed in this respect. While the classroom is mentioned more in previous curricula as a learning environment, out-of-school environments (museums, zoos, etc.) are mentioned in the curricula of 2013 and 2017.

\subsection{Measurement-Evaluation Element of the Curriculum}

The analysis results in relation to Measurement-evaluation, which is the last element of the curriculum, are presented in Table 5.

Table 5. Differences in relation to the measurement-evaluation element of the science curricula

\begin{tabular}{|c|c|c|c|c|c|}
\hline & Curriculum of 1992 & Curriculum of 2001 & Curriculum of 2005 & Curriculum of 2013 & Curriculum of 2017 \\
\hline 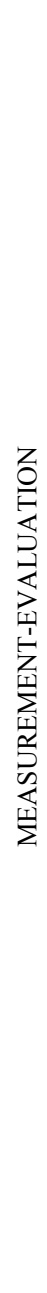 & $\begin{array}{l}\text { No general } \\
\text { explanation was made } \\
\text { in the curriculum for } \\
\text { "Measurement- } \\
\text { evaluation". } \\
\text { However, directive } \\
\text { expressions that end } \\
\text { with "Saying, Writing, } \\
\text { Having made, Having } \\
\text { listed" were used in } \\
\text { general. is } \\
\text { When the whole } \\
\text { curriculum is } \\
\text { examined, it in the } \\
\text { observed that } \\
\text { measurement- } \\
\text { evaluaton expressions } \\
\text { defined are generally } \\
\text { based on "Traditional } \\
\text { measurement- } \\
\text { evaluation" } \\
\text { approaches. }\end{array}$ & $\begin{array}{l}\text { A general explanation } \\
\text { was made in the } \\
\text { curriculum } \\
\text { measurement- } \\
\text { evaluation under the } \\
\text { title "Evaluation } \\
\text { Activities". } \\
\text { It was mentioned that } \\
\text { multiple-choice written } \\
\text { exams fail to measure } \\
\text { student success alone. } \\
\text { To this end, it was } \\
\text { emphasised that the } \\
\text { results of measurement } \\
\text { should be evaluated } \\
\text { with the observation } \\
\text { results obtained by } \\
\text { observing the } \\
\text { behaviours } \\
\text { attitudes of students in } \\
\text { the classroom. To this } \\
\text { end, the curriculum } \\
\text { contains "the Student } \\
\text { Observation Form". } \\
\text { Guiding students to } \\
\text { project, group working } \\
\text { methods is also in } \\
\text { question. } \\
\text { "Self-Evaluation Form } \\
\text { and Group (Cluster) } \\
\text { Evaluation Form" are } \\
\text { included to evaluate } \\
\text { this (2000, } \\
\text { 1008-1010). }\end{array}$ & $\begin{array}{l}\text { In the curriculum, it was } \\
\text { emphasised that it is } \\
\text { necessary to apply } \\
\text { multiple evaluation } \\
\text { methods in which } \\
\text { students can exhibit } \\
\text { their knowledge, skills } \\
\text { and attitudes, and } \\
\text { traditional and } \\
\text { alternative techniques } \\
\text { were used for } \\
\text { measurement and } \\
\text { evaluation. it was } \\
\text { Moreover, it more } \\
\text { emphasised that mearning } \\
\text { alternative measurement } \\
\text { and evaluation } \\
\text { techniques should be } \\
\text { used as they measure } \\
\text { not only the product but } \\
\text { also the lears. } \\
\text { process. }\end{array}$ & $\begin{array}{l}\text { Starting from the fact } \\
\text { that the numerical data } \\
\text { obtained } \\
\text { traditional } \\
\text { measurement tools } \\
\text { under the title } \\
\text { "Measurement and } \\
\text { Evaluation } \\
\text { Understanding" in the } \\
\text { curriculum do not } \\
\text { make a sense alone, it } \\
\text { is suggested to pay } \\
\text { attention to such } \\
\text { aspects as; } \\
\text {-using complementary } \\
\text { evaluation tools and } \\
\text { techniques, } \\
\text {-self and peer } \\
\text { assessments, } \\
\text {-multiple evaluation } \\
\text { opportunities, and } \\
\text {-using the technology } \\
\text { (2013, p. IV). }\end{array}$ & $\begin{array}{l}\text { A three-stage practice } \\
\text { was mentioned in the } \\
\text { curriculum with "the } \\
\text { Approach of } \\
\text { Measurement and } \\
\text { Evaluation". These } \\
\text { stages that are } \\
\text { summarized in the } \\
\text { form of a table were } \\
\text { defined as "Getting to } \\
\text { know, } \\
\text { Monitoring-shaping } \\
\text { and Result (product) } \\
\text { oriented" (2017, pp. } \\
\text { 8-9). The table also } \\
\text { includes the aims and } \\
\text { tools. } \\
\text { It is also said in this } \\
\text { part that } \\
\text { measurement- } \\
\text { evaluation } \\
\text { understanding aimed } \\
\text { at providing constant } \\
\text { feedback to support } \\
\text { meaningful and } \\
\text { permanent learning in } \\
\text { students } \\
\text { monitoring, guiding, } \\
\text { and } \\
\text { learning difficulties } \\
\text { of students in the } \\
\text { process was adopted" } \\
\text { (2017, p. 8). }\end{array}$ \\
\hline
\end{tabular}


Upon examining the science curricula in terms of the Measurement and evaluation element, it is observed that while traditional measurement and evaluation tools were used in the curriculum of 1992, self-assessment tools enabling students to evaluate themselves were mentioned by realizing that the previous evaluations were insufficient. Nevertheless, the fact that this cannot be implemented sufficiently was also emphasised in the 2004 draft curriculum published by the MNE itself (MNE, 2004, p. 39). Consequently, it can be said that traditional measurement and evaluation methods-techniques are still used in the curricula of 1992 and 2001. In addition to traditional evaluation, alternative measurement and evaluation tools were also emphasised in the curriculum of 2005 , and it was said that not only the product but also the process should be evaluated. An effort was shown to support teachers by giving various examples in the curriculum in this respect. Furthermore, in-service training works were carried out for teachers both in the provinces where the Pilot application took place and other provinces during the preparation of the curriculum (Akamca et al., 2006, pp. 347-360). The points of using the technology were emphasised in multiple evaluation and measurement evaluation in the curriculum of 2013. Accordingly, it can be said that there is a transition from centring only around the product to centring around the process and using the multiple evaluation opportunities. Indeed, the opinions of science teachers on the curriculum were examined in the study carried out with 9 science teachers by Toraman \& Alc1 (2013), and it was shown that they stated that the curriculum was positive in terms of target, content and process evaluation.

It is observed that a similar approach is also defended in the curriculum of 2017. In the curriculum, it was endeavoured to explain the measurement and evaluation techniques in a more detailed way with a table, and the importance of feedback was expressed. However, no detailed explanation was given on how to evaluate the project and product that students would prepare with their friends in the Applied science unit added at the end in all grade levels as of the 4th grade. It is believed that this may constitute a problem in terms of teachers who have started to implement the curriculum.

\section{Discussion and Conclusion}

In this study, in which the curricula of primary education (primary school) science lessons implemented in Turkey (1992, 2001, 2005, 2013 and 2017) were addressed comparatively, the curricula were examined in terms of 4 main elements. The comments on each element are given under the relevant tables. The results and discussions in relation to each element are presented below.

1) The change in the aim and gains (targets) element of the curricula can be observed clearly. The number of the aims decreased as a transition to the Cognitive learning approach from the Behavioural learning approach was realized in the curriculum of 1992. Consequently, it can be thought that the understanding of less information is better has been adopted rather than loading students with information, and the curricula have developed towards features that can also be supported by teachers in the system by transforming in many respects. It is observed that similar features are emphasised in the studies carried out. In the study they carried out on 203 teachers in Izmir province, Akpınar, Günay and Hamurcu determined that teachers had positive opinions on the curriculum of 2001 when compared to the curriculum of 1992. Akamca, Günay, \& Hamurcu (2006 and 2008), who achieved similar results in the studies on the implementation of the pilot scheme of the curriculum of 2005 , revealed that teachers generally had positive opinions on the new curriculum, while parents were indecisive, but both groups thought that they were not sufficiently informed about the subject. In a study conducted with 23 teachers, Bümen (2005) defined that teachers believed that the content of the new science curriculum decreased. In their study, Gömleksiz \& Bulut (2007) also tried to determine the effectiveness of the new primary school Science and Technology Curriculum in practice based on teacher opinions. To this end, they developed the Likert-type Science and Technology Course Curriculum Scale consisting of 32 items and applied it to 383 primary school teachers in total, who worked at 64 pilot schools in Istanbul, Ankara, Izmir, Kocaeli, Van, Hatay, Samsun and Bolu provinces where the new Science and Technology Course Curriculum was implemented. The data were comparatively analysed by the variables of province and classroom size. According to the findings obtained, it was found out that the gains, scope, educational status and evaluation provided for in the curriculum were effective at a "high" level. Furthermore, while a difference was found between teacher opinions in terms of the variable of province, no difference was found in terms of the class size variable.

Tekbiylk \& Akdeniz (2008), who performed a similar study with 5 primary school teachers working at various primary schools in Rize province Çayeli district using semi-structured interviews, determined that teachers adopted the new Science and Technology Course Curriculum that started to be implemented in the 2004-2005 academic year, believed in the success of the curriculum, showed an effort to implement the curriculum, but they encountered certain problems since they were not familiar with the curriculum sufficiently. In the study of Tüysüz \& Aydın (2009), it was aimed to determine the opinions of science and technology teachers working at the primary schools in Izmir in the 2007-2008 academic year regarding the new curriculum. To this end, the 
5-point Likert-type scale prepared regarding the new curriculum was applied to 312 Science and Technology teachers, and the data obtained were analysed. According to the results obtained, most of the teachers stated that the curriculum fitted the level of students, took into consideration the level of development of students, the curriculum was prepared in a student-centred way, allowed students to discover the information, and was quite suitable for group work. However, students said that it was quite hard to apply the curriculum in crowded classes.

It is observed that generally positive opinions have been determined for the changing, new curriculum in most of the above-mentioned studies. However, it is also observed that different results have been obtained in certain studies carried out. For example, Ünal, Çoştu, \& Karataş (2004) examined the science curricula developed in our country so far with a critical point-of-view taking into consideration the stages of planning, application and evaluation. In the examinations carried out, they concluded that detailed requirement analyses were not performed adequately at the planning stages of the curricula, conditions that were required in the process of application were not provided to all schools, and effective evaluations could not be performed after the application. In a study carried out in 2006; Buluş, Kırıkkaya and Tanrıverdi also concluded that the gains were not realized sufficiently. In another study, Yangın \& Dindar (2007) collected data by applying a survey to 75 primary school teachers teaching science and technology course at primary schools located in Ankara during the 2005-2006 academic year. According to the results obtained, they determined that the opinions of the 4th and 5 th-grade teachers on the lesson in line with the 2004 science and technology curriculum changed negatively during the teaching process. The researchers think that this result is caused mostly by the problems that occur during the process of application. In this case, it is emphasised in the study that studies should be increased in number to review the aims in the science and technology curriculum and the education system, make structural changes, and incorporate the subjects of science-technology-society into the curriculum. Bağcı Kıliç et al. (2008) also emphasised similar deficits in the evaluation of the 2005 curriculum in terms of science literacy and SPS skills. The researchers observed that the researching nature and scientific information dimensions of science were emphasised more in the curriculum, the dimension of the interaction of science-technology-society was emphasised less, while the science leading to information dimension was emphasised very little. No balance was found between different dimensions of science literacy in gains and activities. Upon examining in terms of science process skills, it was found out that basic scientific process skills were emphasised more than combined scientific process skills.

In the study comparing especially the curricula of 2005 and 2013, it is observed that Karatay et al. (2013) achieved similar results. The researchers defined the changes made in relation to the gains, science literacy, and the arrangement of units.

While all these results obtained emphasise the positive aspect in the change of the curriculum, it shows that problems that are still encountered in the application, source supply, in-service teacher training and class size affect the implementation of the curriculum. The 2017 curriculum started to be implemented in the 3rd and 5th grades as of the 2017-2018 academic year. It is believed that the analysis of the situation will be more suitable by conducting studies again after the implementation of the curriculum.

2) Upon examining in terms of the content, which is the second element of the curriculum; it is observed that the learning approaches on which the curricula are based change from the behavioural approach to the research-inquiry based approach. This situation is considered important because it represents a fundamental change in learning approaches in Turkey. It is observed that the student is considered as a person who takes the information as it is and reflects it on his/her behaviours, while the transition to the cognitive (constructivist) approach is tried to be ensured in the curriculum of 2001, in which the student is centred around and information is structured in the mind of an individual. However, as it is also emphasised by the MNE, it is determined that this transition cannot be fully ensured in the 2004 science curriculum (MNE, 2004, p. 39). This is also specified by Arsal (2012) in the curriculum of 2005. Arsal, who accepted the 5 principles created by examining the relevant literature as criteria for constructivism, investigated all the gains of the 4th and 5th grade Science and Technology course curriculum and determined that it was not prepared in accordance with the principles of the constructivist understanding in general. In the comparison made in 2013, Karatay et al. stated that the curricula of 2005 and 2013 incorporated the constructivist and research inquiry-based learning strategies.

Differences are also observed in the associations made between the curricula and other lessons. While the associations with different areas are not included in the curricula of 1992, 2001 and 2013, they are included in the curriculum of 2005. This is among the aspects that are also emphasised in the study carried out by Bümen (2005). While the teachers that participated in the workshop found the horizontal association of the science and technology curriculum with Turkish and Social sciences lesson more adequate, they stated that sufficient 
integrity with Mathematics lesson could not be ensured. This interaction between different lessons is considered important in the education system in Turkey because the Life sciences course takes place in the first 3 years of the primary school and the Science and Social sciences courses start in the 4th grade. These courses continue in the 5th-8th grades of the secondary school. It is known that topics that constitute the basis of both science and social sciences courses are included within the scope of the Life sciences course. In this case, students get prepared for the science and social sciences courses in the first 3 years. It is known that it is recommended to teach science, Turkish, life sciences, social sciences, etc. by associating them with each other as a general approach. The teachers also stated that the content in the 4th and 5th grades supported one another vertically. Bahar (2006), who investigated the curriculum in terms of the principle of spirality, determined that this feature was not adequate in certain units. Aktaş \& Hamurcu (2010), and Aktaş, Hamurcu, \& Günay (2011) who carried out two different studies in the same subjects determined that the content of the units in the curriculum was generally prepared in accordance with the principle of "spirality", although this was not exactly the case in certain subjects. It can be said that this principle is also generally complied with in the curriculum of 2013 . Nevertheless, it is observed that this structure is deteriorated in the 2017 curriculum. The successiveness of the units in the 3rd and 4th grades cannot be ensured in the subject area of "Living beings and life". The 3rd grade covers the unit "Our five senses". The unit "Our food" is given in the 4th grade. Nevertheless, children should first get the information about themselves in the process of education according to the proximodistal principle. The information about "Our body and systems" which can follow the sensory organs is given in the 6th grade (MNE, 2017, p. 13). However, in the previous curricula (2005 and 2013), information on the children's own body and systems continued in the 3rd, 4th, 5th... and other grades successively. It is not known why this successiveness has been broken (and even by skipping to the 6th grade from the 3rd grade). If it has been aimed to inform students about the balanced diet, obesity, etc. subjects by teaching them the subject of Food, it is estimated that this requirement can be fulfilled by replacing the new unit.

When the content of the curriculum is addressed in terms of technology subjects, it is observed that while technology was mentioned in the introduction parts of the 1992 and 2001 curricula, it was attributed significant importance as of the curriculum of 2005 also as a requirement of the contemporary society, and the intertwinement of science and technology was emphasised. Nevertheless, we can see that technology is not included in the general aims in the curriculum of 2017, while technological development and innovation are emphasised with the field of science and engineering practices added. It is remarkable that subjects related to the environment and health are attributed importance in all curricula. However, it is observed that information on health is given in one grade and one unit since the units are reduced in number in the curriculum of 2001.

3) When the data on the Educational Status (Learning-teaching process) element of the curricula are examined, it is observed that learning and teaching strategies are included in all curricula apart from the curriculum of 1992. It is observed that the learning and teaching process that was teacher-centred in 1992 moved towards being student-centred in the curriculum changes in subsequent years. Especially after 2001, it was emphasised that the teacher is the person who guides and not manages, by taking the student in the centre. Although the extent to which this transition was fulfilled is a matter of discussion, this message is clear when explaining "the role of the student" in the curricula $(2005,2013$ and 2017). In the study in which they compared the curricula of 1968, 1992, 2000 and 2004, Dindar \& Taneri (2011, p. 376) also attracted attention to the student-centeredness especially in the curricula of 2000 and 2004.

Nevertheless, although the learning environment is mentioned as being student-centred, it is known that teachers encounter various problems in the process of application. Just as it is determined in the studies (Kan, 2005; İnce, 2005; Çınar, 2006) quoted by Gömleksiz \& Bulut (2007), teachers with no sufficient experience on this subject tried to implement the new curriculum. Çepni et al. (2003) tried to determine the problems encountered by teachers when carrying out the science curriculum. In their studies, they collected the data with semi-structured interviews conducted with 25 primary school teachers, 27 science teachers and 7 science instructors. It was observed from the data that most of primary school teachers did not teach Science willingly, had difficulty in performing laboratory practices, and they thought that it would be more suitable if branch teachers taught these lessons.

Akamca, Hamurcu, \& Günay (2006) also determined that teachers addressed problems especially such as the lack of tools, materials, reference materials, and crowded classes after the curriculum of 2005, and demanded in-service training. Similar results were achieved in the studies of Tekbıyk \& Akdeniz (2008). The researchers determined that teachers encountered certain problems since they were not familiar with the curriculum sufficiently. In a similar way, Tüysüz \& Aydın (2009) determined that teachers at research schools in Buca district of Izmir province emphasised the positive aspects, student-centeredness, etc. of the curriculum, but they 
encountered certain difficulties in the application of this curriculum with crowded classes. In the study conducted by Buluş Kırıkkaya (2009), the opinions of science teachers on the curriculum were investigated. It was determined that teachers had positive opinions on the curriculum after the in-service training course in which they participated, such as "student-centeredness, emphasising learning by doing, attributing importance to experiment and observation, leading students to researching, attenuation of subject levels, spiral units, and popularizing science lessons" (2009, p. 141).

Similar results were obtained in the study conducted by Unayağyol (2010) in the surroundings of Yozgat province. According to the results of the analysis carried out on 255 primary school teachers and 70 science teachers, teachers generally talked positively of the 2005 curriculum. However, they also mentioned problems they encountered during the implementation process of the curriculum. Teachers stated that problems such as the lack of tools-materials, not being informed sufficiently about the curriculum, crowded classes and inadequate books were effective in their failure to apply the curricula to the desired extent.

Özdemir \& Arık (2017) investigated the opinions of Science $(n=99)$ and Primary School Teachers $(n=26)$ working in primary and secondary schools on the curricula of 2005 and 2013 using a survey. According to the data obtained by the researchers, there were significant differences between teacher opinions on the elements of the old and new curricula. It was observed that teachers found the curriculum positive in terms of the targets, content, process and evaluations in relation to the renewed science curriculum.

Consequently, it can be said that many positive contributions brought about by the changing curricula cannot be realized sufficiently because of the problems encountered in application environments.

4) Upon examining the results in relation to measurement-evaluation, which is the last element of the curriculum, it is observed that while traditional measurement and evaluation tools were used in the curriculum of 1992, they differed in the curricula of 2001, 2005, 2013 and 2017. Self-assessment forms for students were mentioned in 2001, alternative measurement-evaluation tools were emphasised in the curriculum of 2005 , and multiple evaluation and using technology in measurement and evaluation were emphasised in 2013. A table is given in the curriculum of 2017 by focusing on this subject in a more detailed way. Identification, Monitoring and Result assessment aims and means are explained briefly in the table. Furthermore, explanations are made on self-assessment, group and peer evaluations (MNE, 2017, pp. 9-10).

Upon examining the studies conducted on this subject, according to the findings obtained from the study carried out by Gömleksiz \& Bulut (2007) with a total of 383 primary school teachers, it was found out that the evaluation dimension of the 2005 curriculum was effective at a "high" level.

In the study carried out by Güçlü, Kartal, \& Mete (2010) on the measurement and evaluation dimension of the 2005 curriculum with 79 primary school and science teachers in Kurşehir province, it was determined that the opinions of teachers on alternative measurement and evaluation were generally positive. In the study, Unayağyol (2010) concluded that teachers thought that problems were caused especially in the evaluation process of crowded classes. As for the studies conducted on the curriculum of 2013, it was determined that teachers generally thought positively of the process evaluation in the curriculum (Toraman \& Alc1, 2013; Özdemir \& Arık, 2017).

Consequently, it can be said that positive contributions made by changing curricula to the process of measurement and evaluation cannot be implemented sufficiently for various reasons (crowded classes, insufficiency of teachers' knowledge on the subject, etc.).

\section{Suggestions}

Results achieved in this study show that the curricula have changed positively by years. However, the fact that these developments are not realized due to certain problems encountered in the process of application (the fact that teachers are not informed sufficiently, the lack of tools-materials, infrastructure problems, crowded classes, etc.) is among the findings obtained in the studies carried out.

The following suggestions are made based on the findings obtained from this study.

1) In the preparation of the curricula, it is also suggested to conduct studies on taking the opinions of teachers who play a significant role in the application process and help the realization of learning by guiding.

2) Before implementing the changes made in the curricula, it is suggested to give teachers in-service training and therefore provide sufficient experience to implement the curricula effectively. 
3) Evaluations should be performed at suitable intervals to show the problems encountered in the process of implementing the curricula and interfer on time. It should be ensured that the necessary corrections are made in line with the data obtained.

4) The importance of the learning environment in ensuring the aimed gains has been emphasised in many studies. Therefore, it is believed that it will be beneficial to provide the necessary physical conditions (laboratory, classroom layout, order, technological equipment, etc.) for the effective and efficient implementation of the curricula.

\section{References}

Akamca Ö. G., Hamurcu, H. \& Günay, Y. (2008). Fen ve teknoloji programına yönelik öğretmen ve veli görüşleri (İzmir örneklemi) [Opinions of teachers and parents on the science and technology curriculum (Izmir sample)], 7. Ulusal Fen Bilimleri Ve Matematik Eğitimi Kongresi Bildiri Kitabı, (7-9 Eylül 2006) Cilt: II, 666-671. İstanbul: Güzel Sanatlar Matbaası.

Akamca Ö. G., Hamurcu, H., \& Günay, Y. (2006) Yeni ilköğretim fen ve teknoloji programına yönelik öğretmen görüşleri [Teachers' opinions on the new primary school science and technology curriculum], Ulusal Sinıf Ögretmenliği Kongresi Bildiri Kitabl, (14-16 Nisan) Cilt: 1, 347-360. Ankara: Kök Yayıncılık.

Akpınar, D., Hamurcu, H., \& Günay, Y. (2005). Fen bilgisi programlarının hedef ve içerik boyutuna ilişkin öğretmen görüşleri [Teachers' opinions on the target and content dimension of science curricula]. Eğitim ve Bilim Dergisi, 30(136), 3-11. $\quad$ Retrieved from http://egitimvebilim.ted.org.tr/index.php/EB/article/view/5187/1335

Aktaş, Ö., \& Hamurcu, H. (2010). İlköğretimde dördüncü ve beşinci sınıf fen ve teknoloji dersi programında yer alan kavramların sarmallık ilkesi açısından incelenmesi [Investigation of the concepts in the fourth and fifth-grade science and technology course curriculum in primary education in terms of the principle of spirality], IX. Ulusal Fen Bilimleri ve Matematik Eğitimi Kongresi Özet Kitabl, 234. İzmir: Güler Matbaası.

Aktaş, Ö., Hamurcu, H., \& Günay, Y. (2011). Fen ve teknoloji dersi programındaki kavramların İncelenmesi (4-8. siniflar) [Investigation of the concepts in the curriculum of the science and technology course (4-8th grades)], 10. Ulusal Sinıf Öğretmenliği Eğitim Sempozyumu Bildiri Kitabı, (5-7 Mayıs) Cilt: I, 52-57. Sivas: Esform Ofset Matbaasi.

Arsal, Z. (2012). İlköğretim fen ve teknoloji dersi öğretim programı kazanımlarının yapılandırmacılık ilkelerine göre değerlendirilmesi [Evaluation of primary education science and technology course curriculum gains according to the principles of constructivism], Uluslararası Eğitim Programları ve Öğretim Çalışmaları Dergisi, 2(3), 1-14. Retrieved from http://ijocis.com/index.php/ijocis/article/view/21/20

Bağcı, K. G., Haymana, F., \& Bozyılmaz, B. (2008). İlköğretim fen ve teknoloji dersi öğretim programının bilim okuryazarlığı ve bilimsel süreç becerileri açısından analizi [Analysis of the primary education science and technology course curriculum in terms of science literacy and scientific process skills]. Eğitim Ve Bilim Dergisi, 33(150), 52-63. Retrieved from http://egitimvebilim.ted.org.tr/index.php/EB/article/view/630/100

Bahar, M. (2006). 4-8. Sinıflar Fen ve teknoloji öğretim programına genel bir bakış [A general overview of the 4-8th grade Science and technology curriculum] (pp. 432-450). In M. Bahar (Ed.), Fen ve Teknoloji Öğretimi. Ankara: Pegem A Yayıncılık.

Buluş, K. E. (2009). İlköğretim okullarındaki fen öğretmenlerinin fen ve teknoloji programına ilişkin görüşleri [Opinions of science teachers at primary schools on the science and technology curriculum]. Türk Fen Ĕgitimi Dergisi (TUFED/TUSED), 6(1), 133-148. Retrieved from http://www.Tused.org

Buluş, K. E., \& Tanrıverdi, B. (2006). Fen ve teknoloji programında beceri, anlayış, tutum ve değerlerlerle ilgili kazanımların önem derecesi ve gerçekleştirme düzeyi [Level of importance and realization of the gains in relation to the skills, understanding, attitudes and values in the science and technology curriculum]. Eğitim Araştırmalarl, $\quad 6(25), \quad 129-140 . \quad$ Retrieved from http://www.ejer.com.tr/tr/index.php?git=22\&kategori=56\&makale=293

Bümen, N. T. (2005). Öğretmenlerin yeni ilköğretim 1-5. sınıf programlarıyla ilgili görüşleri ve programı uygulamaya hazırlayıcı bir hizmetiçi eğitim çalışması örneği [Opinions of teachers on the new primary school 1-5th grade curricula and an example of in-service training study as a preparation for the implementation of the curriculum]. Ege Eğitim Dergisi, 6(2), 21-57. Retrieved from http://dergipark.gov.tr/download/article-file/57084 
Çepni, S., Küçük, M., \& Ayvacı, H. Ş., (2003) İlköğretim birinci kademedeki fen bilgisi programının uygulanması üzerine bir çalışma [A study on the implementation of the science curriculum at the first level of primary school]. Gazi Eğitim Fakültesi Dergisi, 23(3), 131-145. Retrieved from http://gefad.gazi.edu.tr/article/view/5000078826/5000073044

Dindar, H., \& Taneri, A. (2011). MEB'in 1968, 1992, 2000 ve 2004 yıllarında geliştirdiği fen programlarının amaç, kavram ve etkinlik yönünden karşılaştırılması [Comparison of the science curricula developed by the MNE in 1968, 1992, 2000 and 2004 in terms of aims, concepts and effectiveness]. Kastamonu Ĕgitim Dergisi, 19(2), 363-378. Retrieved from http://www.kefdergi.com/pdf/19_2/19_2_1.pdf

Eş, H., \& Sarıkaya, M. (2010). Türkiye ve İrlanda fen öğretimi programlarının karşılaş̧ırılması [Comparison of the science curricula in Turkey and Ireland]. Ilkögretim Online, 9(3), 1092-1105. Retrieved from http://Illkogretim-Online.Org.Tr

Gömleksiz, N., \& Bulut, İ. (2007). Yeni fen ve teknoloji dersi öğretim programının uygulamadaki etkililiğinin değerlendirilmesi [Evaluation of the effectiveness of the new science and technology course curriculum in practice]. Hacettepe Üniversitesi Eğitim Fakültesi Dergisi, 32, 76-88. Retrieved from http://www.efdergi.hacettepe.edu.tr/makale_goster.php?id=580

Güçlü, N., Kartal, T., \& Mete, F. (2010). İlköğretim fen ve teknoloji programında değerlendirme boyutuna ilişkin öğretmen görüşleri [Opinions of teachers on the evaluation dimension in the primary school science and technology curriculum]. I. Ulusal Ĕgitim Programları ve Öğretim Kongresi Tam Metinler Kitabı, (13-15 Mayıs), 428-433. Balıkesir, Pegem Akademi.

Hamurcu, H. (1998). Sekiz yıllık eğitimde fen programları [Science curricula in the eight-year education]. Sekiz Yıllık Eğitimde Fen ve Matematik Öğretimi Sempozyumunda Sunulan Bildiri. İstanbul.

Karatay T., Timur S., \& Timur B. (2013). 2005 ve 2013 yılı fen dersi öğretim programlarının Karşılaştırılması [Comparison of the 2005 and 2013 science curricula]. Adlyaman Üniversitesi Sosyal Bilimler Enstitüsü Dergisi, 15, 233-264.

MEB. (1992). İlköğretim kurumlart fen bilgisi dersi öğretim programları [Science curricula of education institutions]. Milli Eğitim Basımevi: İstanbul.

MEB. (2000). Fen bilgisi dersi ögretim programı [Science course curriculum]. Milli Eğitim Bakanlı̆̆ı Tebliğler Dergisi.

MEB. (2004). Fen ve teknoloji dersi ögretim programı [Science and technology course curriculum]. MEB Yayını (Taslak).

MEB. (2013). Fen bilimleri dersi ögretim programı [Science course curriculum]. MEB Talim ve Terbiye Kurulu Başkanlığı. Retrieved from http://ttkb.meb.gov.tr/www/ogretim-programlari/icerik/72

MEB. (2017). Fen bilimleri dersi ögretim programı [Science course curriculum], MEB Talim ve Terbiye Kurulu Başkanlığı. Retrieved from http://mufredat.meb.gov.tr/ProgramDetay.aspx?PID=143

Özdemir, E., B., \& Arık, S. (2017). 2005 yılı fen ve teknoloji dersi ve 2013 yılı fen bilimleri dersi öğretim programlarının öğretmen değerlendirmesi [Teacher evaluation of the 2005 science and technology course and the 2013 science course curricula], Ahi Evran Üniversitesi Kırşehir Eğitim Fakültesi Dergisi (KEFAD), 18, 31-44. Retrieved from http://kefad.ahievran.edu.tr/Kefad/ArchiveIssues/PDF/1571c260-d65b-e711-80ef-00224d68272d

Saylan, N. (1995). Ëgitimde Program tasarısı temeller-prensipler-kriterler [Curriculum design in education bases-principles-criteria]. Balıkesir: İnce Ofset.

Tekbıyık, A., \& Akdeniz, A., R. (2008). İlköğretim fen ve teknoloji dersi öğretim programını kabullenmeye ve uygulamaya yönelik öğretmen görüşleri [Opinions of teachers on adopting and implementing the primary school science and technology course curriculum]. Necatibey Eğitim Fakültesi Elektronik Fen Ve Matematik Ë̆itimi Dergisi (EFMED), 2(2), 23-37. Retrieved from http://www.nef.balikesir.edu.tr/ dergi/makaleler/yayinda/5/EFMED_FBE110.pdf

Toraman, S., \& Alc1, B. (2013). Fen ve Teknoloji öğretmenlerinin yenilenen fen bilimleri dersi öğretim programına ilişkin görüşleri [Opinions of Science and Technology teachers on the renewed science course curriculum], EKEV Akademi Dergisi, yıl: 17, 56, 11-22. Retrieved from http://www.ekevakademi.org/Makaleler/1343724831_02\%20Sinem\%20TORAMAN-Bulent\%20ALCI.pdf 
Tüysüz, C., \& Aydın, H. (2009). İlköğretim fen ve teknoloji dersi öğretmenlerinin yeni fen ve teknoloji programına yönelik görüşleri [Opinions of primary school science and technology teachers on the new science and technology curriculum]. Gazi Eğitim Fakültesi Dergisi, 29(1), 37-54. Retrieved from http://gefad.gazi.edu.tr/article/view/5000078557/5000072778

Ünal, S., Çoştu B., \& Karataş, F. Ö. (2004). Türkiye'de fen bilimleri eğitimi alanındaki program geliştirme çalışmalarına genel bir bakış [A general overview of the curriculum development studies in Turkey in the field of science education]. Gazi Ĕgitim Fakültesi Dergisi, 24(2), 183-202. Retrieved from http://gefad.gazi.edu.tr/article/view/5000078796/5000073014

Unayağyol, S. (2010). Öğretmenlerin fen ve teknoloji programının uygulanması sürecinde karşılaştığı sorunlar ve çözüm önerileri (Yozgat ili örneği) [Problems encountered by teachers in the process of the implementation of the science and technology curriculum and solution suggestions (Example of Yozgat province)]. I. Ulusal Ĕgitim Programları ve Ögretim Kongresi Tam Metinler Kitabl, (13-15 Mayıs) 609-614. Balıkesir, Pegem Akademi.

Varış, F. (1994). Eğitimde program geliştirme: teori ve teknikler [Curriculum development in education: theory and techniques]. Ankara: Alkım Yayıncılık.

Yangın, S., \& Dindar, H. (2007). İlköğretim fen ve teknoloji programındaki değişimin öğretmenlere yansımaları [Reflections of the change in the primary school science and technology curriculum on teachers], Hacettepe Üniversitesi Eğitim Fakültesi Dergisi, 33, 240-252. Retrieved from http://www.efdergi.hacettepe.edu.tr/makale_goster.php?id=1044

Yıldırım, A., \& Şimşek, H. (2000) Sosyal bilimlerde nitel araştırma yöntemleri [Qualitative research methods in social sciences], 2.Bask1, Ankara: Seçkin Yayınevi.

\section{Note}

A short summary of the present study was presented at the 22nd National Education Sciences Congress held by Eskişehir Osmangazi University between 5 and 7 September 2013. However, the study was revised with the amendment made in 2017.

\section{Copyrights}

Copyright for this article is retained by the author(s), with first publication rights granted to the journal.

This is an open-access article distributed under the terms and conditions of the Creative Commons Attribution license (http://creativecommons.org/licenses/by/4.0/). 